\title{
협수로에서 생성되는 고립파 형태의 항주파와 항주파류 Solitary Wave-like Ship Induced Waves and Its Associated Currents in a Water Channel of Narrow Width
}

\author{
조용준* · 최한림* \\ Yong Jun Cho* and Han Rim Choi*
}

\begin{abstract}
요 약: 가용한 토지의 부족으로 현재 우리나라 인공운하에서 흔히 관측되는 협수로에서는 고립파 형태의 항주파 가 생성되는 것으로 추정된다. 본고에서는 이러한 가설을 확인하기 위해 수치모의를 수행하였다. 수치모의는 삼차 원 Navier Stokes 식과 VOF에 기초하여 수행되었으며, 수치모형의 검증은 현재 우리에게 가용한 운하 설계기준 중 가장 빈번히 언급되는 PIANC (1987) 설계안과 본고에서 유도된 해석해에 기초하여 수행되었다. 모의결과, 고립파 형태의 항주파가 관측되었으며, 하안 인근에서 계측된 선수파 파고의 경우 수치모의 결과는 PIANC (1987) 설계안 을 상회하였으며 상당히 오랜 기간 (이십초 내외) 지속되었다. 선미파의 경우는 하회하였다. 이러한 결과는 광역수 로에서 관측되는 항주파의 일반적인 특성과는 상이한 것으로 좁은 수로 폭이 항주파 특성에 영향을 미치는 것으로 판단된다. 또한 선박의 협수로 통과시 선박을 중심으로 양안으로 진행되는 흐름과, 반사로 인해 양안에서 선박으로 진행되는 흐름이 교대로 출현하였으며 이 때 최대 $0.90 \mathrm{~m} / \mathrm{s}$ 의 유속이 전 수심대역에서 비교적 균일하게 유지되어, 상 당한 쇄굴이 진행될 수 있다고 판단된다.
\end{abstract}

핵심용어 : 협수로, 항주파 해석해, 고립파, Navier Stokes Eq., VOF

\begin{abstract}
In the narrow water channel, which has been frequently deployed in the artificial canal in the South Korea due to the lack of available land, solitary wave type ship induced waves can occur. In order to test this hypothetical view, we carried out the numerical simulation. Numerical model consists of Navier-Stokes Equations and VOF, and the verification is implemented using the data by PIANC (1987) and the analytical model derived in this study. It was shown that numerically simulated front wave height are much larger than the one by PIANC (1987), and the fluctuation of free surface near the channel bank persists much longer (around 20s). For the case of stern waves, numerically simulated wave height are somewhat smaller than the data by PIANC (1987). These results seriously deviates from the general characteristics of ship induced waves observed in the wide water channels, and leads us to conclude that ship induced waves is severely affected by the width of water channel. It was also shown that the currents from the channel banks toward a ship, and currents from the ship toward the channel banks are alternatively occurring due to reflection at the channel banks. The velocity of currents reaches its maximum at $0.90 \mathrm{~m} / \mathrm{s}$, and these values are sustained through the entire depth. which implies that severe scourings at the channel bottom can be underway.
\end{abstract}

Keywords : water channel of narrow width, ship induced waves, solitary waves, Navier Stokes Eq., VOF

\section{1. 서 론}

최근 급증한 친수공간에 대한 수요를 충족하기 위해 여러 인공운하가 검토되고 있거나, 혹은 기 시공되어 운영되고 있 다. 현재 검토단계에 있거나 운영 중인 운하의 대부분은 수 자원 확보가 비교적 용이하다는 점과, 수도권으로 부터의 접 근성이 수월하다는 장점으로 인해 서해안과 연계되어 있다. 전술한 운하들은 친수공간으로서의 역할 뿐만 아니라, 기후 변화에 따른 집중호우로 인한 침수 저감을 위한 유수지와 교
통량 분산을 목적으로 한 주운의 기능도 담고 있으나, 경인 아라 뱃길처럼 예산상의 제약으로 충분한 수면적 확보에 어 려움을 겪고 있는 것으로 보인다. 이는 자연하천과 갑문에 기 초한 구주의 운하와는 전혀 다른 수환경으로, 협수로를 선박 이 통과하는 경우 상당한 크기의 고립파 형태의 항주파가 발 생할 수 있다 (Herbich and Schiller, 1984). 이렇게 생성된 고립파는 상당한 처오름 높이와 호안 피복석의 유실로 이어 질 수 있어 상당한 주의가 필요해 보이나 (Maynord, 2004), 현재 우리나라는 상대적으로 일천한 운하 시공 및 운영 경험

*서울시립대 토목공학과(Corresponding author: Yong Jun Cho, Department of Civil Engineering, University of Seoul, Seoul 130-743, Korea, Tel:+82-2-6490-2427, Fax:+82-2-6490-2424, young@uos.ac.kr) 
으로 인해 운하를 주행하는 선박의 적정 선속에 대한 기준조 차 마련되어 있지 못한 실정으로 이에 대한 연구가 시급해 보 인다. 이와 더불어 협수로의 경우 선박 주행 시 선체의 동요 로 인해 수로 수체는 unit body mode로 요동하며, 이 경우 수로 하저에서는 극심한 세굴이 진행되는 것으로 보고되어 협 수로 설계 시 세심한 고려가 필요해 보인다 (Taylor et al., 2007; HCCL, 2005).

협수로를 운행하는 선박에 의한 고립파 생성은 Russel(1838)이 수리실험을 수행하는 과정에서 처음 그 모습 을 드러낸 이후, 많은 연구가 이루어져 Boussinesq Eq.의 해 석해에 기초한 고립파 파형이 Rayleigh에 제시된 바 있다. 전 술한 고립파 파형은 지진으로 생성된 파형을 가장 정교하게 모의할 수 있다는 장점으로 인해 현재 지진해일 해석에 널리 차용되고 있으나 tsunami 생성 초기 발생하는 해수면의 강하 를 담고 있지 않아 처오름 높이가 다소 과소하게 모의되는 것 으로 알려졌다. 이후 Keulegan (1948)은 고립파 전파과정에 서 점성에 의한 감쇄가 미치는 영향까지 연구범위를 확대하 였다.

현재 운하를 주행하는 선박의 적정 선속 결정시 우리에게 가용한 기준으로는 PIANC (1987)가 권하는 수치가 유일하 나, 전술한대로 구주의 수환경과 우리의 그것과는 상당한 차 이가 있어 상당한 논의가 필요해 보인다.

이러한 인식에 기초하여 본고에서는 현재 검토가 진행 중 인 송도 운하에 담겨있는 수로를 대상으로 선박의 협수로 통 과시 생성되는 고립파 특성과, 고립파 제어를 위해 요구되는 선박의 적정 선속을 결정하기 위한 수치모의가 수행된다.

\section{2. 항주파}

\section{1 항주파 종류와 물리적 특성}

선박이 주행하면 선체주위 유체의 유속은 증가하며 수면 은 가라앉는다. 이렇게 생성된 파랑을 선수, 선미파와 더불 어 항주 제일파라 칭한다. 이 때 선체를 따라 수위는 고르 지 않으며 이로 인해 생성되는 횡파, 발산파는 항주 제이파 라 불린다.

강력한 항주 일파는 만재 화물선에 의해 생성되며 호안에 서 $0.3 \sim 0.5 \mathrm{~m}$ 까지 이르며 20초에서 60 초 정도 지속된다. 선 미파와 선수파의 주기는 2 5초 사이에 분포하며 강력한 항 주 이파는 빠르게 진행하는 보트 등에 의해 생성된다.

항주파의 물리적 특성은 교란파 이송속도 $\sqrt{g h}$ 와 선반 운 행속도 $V_{S}$ 비로 정의되는 Froude NO. $F r_{D}$ 에 의해 결정되 며 는 다음과 같이 기술될 수 있다.

$$
F r_{D}=\frac{V_{S}}{\sqrt{g h}}
$$

여기서 $h$ 는 수심을 나타내며 선박이 교란파 이송속도보다 느리게 이동하는 경우 $F r_{D}$ 는 1보다 작으며 이를 sub-critical regime이라 한다. 이에 비해 선속이 교란파 이송속도와 같은 경우 $F_{D}$ 는 일의 값을 지니며 이때의 선속을 임계속도라 칭 하며, 선박이 교란파 이송속도보다 빠르게 이동하는 경우 $F_{D}$ 는 일보다 큰 값을 지니며 이러한 경우를 super critical regime 이라 정의한다.

일본항만설계기준 (Japanese Ministry of Land, Infrastructure, Transport and Tourism, 1999)에 준하면 $F r_{D} \leq 0.7$ 인 경우 항 주파는 심해파로 거동하며 선박의 항로중심에서 $90^{\circ} \sim 35^{\circ}$ 의 각 도로 전파되는 발산파와 $35^{\circ} \sim 0^{\circ}$ 로 진행되는 횡파로 구성되며 첨두선 (cuspline) 내에 발산파와 횡파가 고립되는 고전적인 쐐기 형태의 Kelvin wash 형상이 발현된다.

$F_{D}$ 이 1에 근접하는 경우 항주파의 전파양상은 급격히 변 하여 횡파는 거의 소멸되며 선박의 전면에는 임계파(critical wave)가 발달하며 $F r_{D}$ 이 더욱 커지는 경우 선도 파랑의 마 루를 잇는 선은 거의 직선으로 일어서게 된다.

선박이 심해에서 sub-critical 의 선속으로 진행하는 경우 첨 두선(cuspline)과 선박의 항행선이 이루는 쐐기의 반각은 $F r_{D}$ 가 0.4 보다 작은 경우 $19.5^{\circ}$ 의 최소값을 지닌다. 쐐기의 반각은 $F r_{D}$ 가 증가함에 따라 점차 증가하여 $F r_{D}=1.0$ 에서 정점 $\left[90^{\circ}\right]$ 을 이루며 $F r_{D}$ 가 더욱 증가하면 다시 감소하게 된다.

\subsection{Solitary wave 형태의 항주파 수리특성}

협수로를 운행하는 선박에 의한 고립파 생성은 Russel(1838)이 수행한 수리실험 과정에서 처음 그 모습을 드 러낸 이후, 많은 연구가 이루어져 Boussinesq Eq.의 해석해 에 기초한 고립파 모형도 Rayleigh에 의해 제시된 바 있다. 이후 Keulegan (1948)은 고립파 전파과정에서 점성에 의한 감쇄가 미치는 영향까지 연구범위를 확대하였으며, 논의를 위 해 고립파 해석 모형을 기술하면 다음과 같다.

$$
\eta=A \operatorname{sech}^{2} K(x-C t)
$$

여기서 $\mathrm{A}$ 는 파고, $K=\left(3 A / 4 h^{3}\right)^{1 / 2}$ 는 Solitary wave의 파 수 혹은 경계감쇄계수, $\mathrm{h}$ 는 수심을 각각 나타내며, $\mathrm{C}$ 는 파속 으로 다음과 같이 정의된다.

$$
\begin{aligned}
C & =(g h)^{1 / 2}\left(1+\frac{A}{h}\right)^{1 / 2} \\
& =[g(h+A)]^{1 / 2}
\end{aligned}
$$

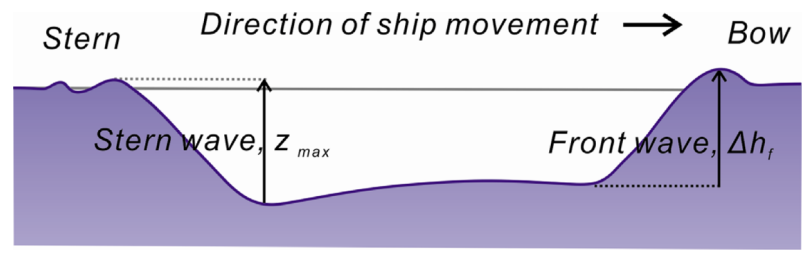

Fig. 1. Definition sketch of ship induced waves. 


\subsection{Solitary wave 형태의 항주파 해석해}

수치모의된 항주파 검증에 활용하기 위해 Solitary wave 형 태의 항주파 해석해를 역적 운동량 방정식, 수심방향으로 평 균된 연속방정식, 선박 전단부에서 선속과 항주파로 인한 유 속은 동일하다는 경계조건으로부터 유도하였으며 유도과정을 정리하면 다음과 같다.

A. 먼저, 협수로를 운항하는 선박으로 생성되는 항주파가 Solitary waves의 성격을 지니며, 선박이 운항을 시작하면 서 서히 증가하는 항주파 파고를 단계별로 상승하는 단파의 조 합으로 해석할 수 있다고 가정한다.

B. 이어 Fig. 2에 도시된 통제용적에 질량보존식과 운동량 보존식을 적용하여 다음과 같은 관계식을 얻는다.

$$
\begin{aligned}
& c_{u} \eta+h \tilde{u}_{2}-(h+\eta) \tilde{u}_{1}=0 \\
& \frac{1}{2} \rho g(h+\eta)^{2}-\frac{1}{2} \rho g h^{2}=\rho \tilde{u}_{2}^{2} h-\rho \tilde{u}_{1}^{2}(h+\eta)
\end{aligned}
$$

이 과정에 연직방향 가속도는 미미하여 압력은 정수압분포 를 추종한다는 가정이 수행되었다.

C. $\tilde{u}_{1}$ 은 상기한 depth averaged continuity 식으로부터 다 음과 같이 근사한다.

$$
\tilde{u}_{1}=\frac{c_{u} \eta}{h+\eta}
$$

D. 통제용적 하류단에 아직 파형이 전이되기 전이라 가정 하면 $\tilde{u}_{2}$ 는 영으로 근사할 수 있으므로, 식 (4), (5)로부터 파 속은 다음과 같이 기술될 수 있다.

$$
c_{u}(t)=\sqrt{g\left(h+\frac{\eta}{2}\right)\left(1+\frac{h}{\eta}\right)}
$$

여기서 $\eta$ 는 시간에 종속하는 생성단계별 단파파고를 나타낸다.

E. 식 (7)을 식 (6)에 대입하고 정리하면 선속 $\tilde{u}$ 와 생성된 항주파 파고 $\eta$ 는 다음과 같은 관계식을 추종한다.

$$
\tilde{u}=\sqrt{g \eta\left(h+\frac{\eta}{2}\right)\left(\frac{1}{h+\eta}\right)}
$$

Fig. 3에는 이해를 돕기 위해 식 (8)에 기초하여 산출한 고 립파 형태의 항주파 파고 등고선도를 도시하였다. 흘수[draft]
가 얕을수록 선속이 빠를수록 항주파 파고가 증가하는 것을 알 수 있다.

\section{3. 항주파의 경험적 해석}

논의를 위해 PIANC (1987)가 권하는 항주파 산출과정을 요약하면 다음과 같다.

A. 선박에 의해 점유되는 유수단면적

$$
A_{m}=\text { 흘수×선폭. }
$$

B. 최적 선박 운항속도

PIANC (1987)가 권하는 적정 선박 운항속도 $V_{L}$ 산출과 정을 요약하면 다음과 같다.

먼저, 다음과 같이 정의되는 경험식으로부터 Froude NO. $F_{L}$ 을 Newton Raphson 등의 수치기법을 활용하여 산출한다.

$$
F_{L}=\left[\frac{2}{3}\left(1-\frac{1}{2} \frac{A_{m}}{A_{c}}+F_{L}^{2}\right)\right]^{3 / 2}
$$

여기서 $A_{c}$ 는 유수단면적을 나타낸다.

둘째, 이렇게 산출된 Froude NO. $F_{L}$ 로부터 적정 선박 운 항속도 $V_{L}$ 는 다음과 같이 산출될 수 있다.

$$
F_{L}=\frac{V_{L}}{\sqrt{g \frac{A_{c}}{b_{w}}}}
$$

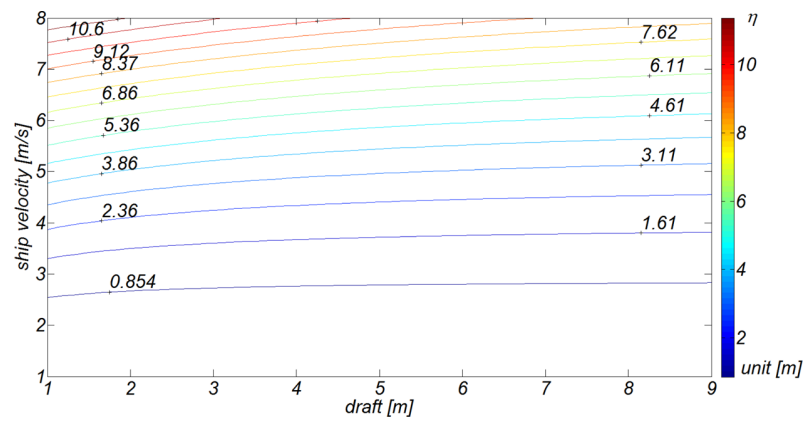

Fig. 3. Contour plot of $\eta$ on draft-ship velocity plane.
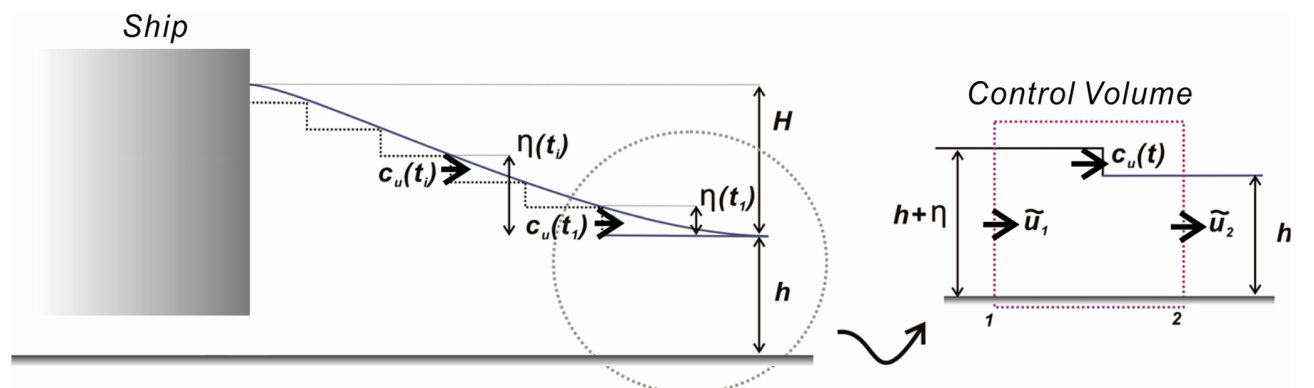

Fig. 2. Schematic sketch of new methodology for the estimation of solitary wave type ship induced waves. 
여기서 $g$ 는 중력가속도, $b_{w}$ 는 자유 수면에서의 수로폭을 나 타낸다 (Fig. 5 참조).

C. 실제 선박 운행 속도

실제 선박 운행 속도 $V_{s}$ 는 승선 혹은 적재정도에 따라 다 음과 같이 조정되며

$$
V_{s}=f_{V} V_{L}
$$

여기서 $f_{V}$ 는 만재시 0.75 , 공선시 0.9 의 값을 지니는 계수를 나타낸다.

이해를 돕기 위해 PIANC (1987)에서 권하는 적정 선박 운 항속도 $V_{L}$ 는 Fig. 3에 도시하였다. 선박 단면적대비 전 유 수단면적이 차지하는 비율에 대해서는 적정 선박 운항속도의 변화는 상대적으로 미미하나 수심에 대해서는 민감하게 변하 는 것을 알 수 있으며, 수심 $1 \mathrm{~m}$ 증가 시 얻을 수 있는 선 속 증가분은 약 $0.3 \mathrm{~m} / \mathrm{s}$ 인 것을 알 수 있다.

D. 평균 수면 강하량 $\Delta h$

평균 수면 강하량 $\Delta h(m)$ 는 다음과 같이 산출되며

$$
\Delta h=\frac{V_{s}^{2}}{2 g}\left[\alpha_{s}\left(\frac{A_{c}}{A_{c}{ }^{*}}\right)^{2}-1\right]
$$

여기서

$\alpha_{s}$ : 최대 허용선속대비 실제 운항속도의 영향을 반영하는 계수로 다음과 같이 정의된다.

$$
\alpha_{s}=1.4-0.4 \frac{V_{S}}{V_{L}}
$$

$A_{c}^{*}$ : 선박운행으로 인한 수면 강하량을 제외한 유수단면 적 $\left[\mathrm{m}^{2}\right]$ (Fig. 5 참조)

$$
A_{c}^{*}=b_{b}(h-\Delta h)+\cos \alpha(h-\Delta h)^{2}-A_{m}
$$

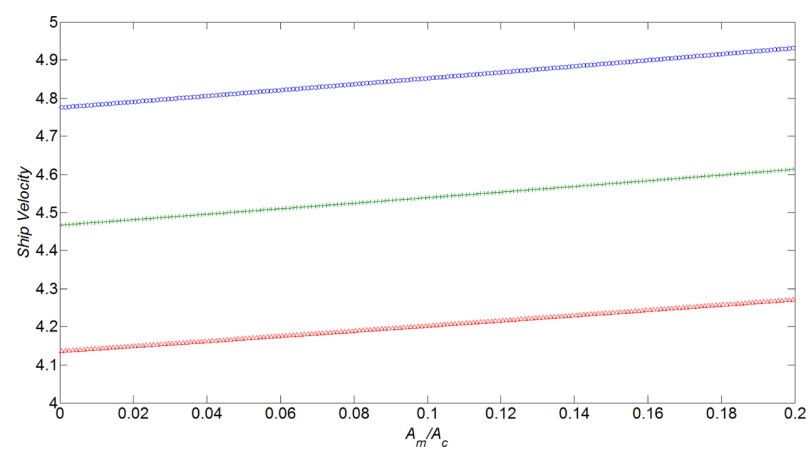

Fig. 4. Trajectory of suggested $V_{L}$ by varying water depth and area ratio of ship over flow area[o:h=8 m, $+: \mathrm{h}=7 \mathrm{~m}, \Delta: \mathrm{h}=6 \mathrm{~m}]$. $b_{b}$ : 하저면에서의 수로폭

$A_{c}$ : 교란되지 않은 상태에서의 유수단면적 $\left(\mathrm{m}^{2}\right)$ 으로 다음과 같이 기술될 수 있다 (Fig. 5 참조).

$$
A_{c}=b_{b} h+h^{2} \cos \alpha
$$

$$
\alpha \text { : 하안 사면 경사각 }
$$

전술한 $A_{c}{ }^{*}$ 는 직접 산출 할 수 없으며, 먼저 $\Delta h$ 가정한 후 오차를 이완하는 방법으로 $\Delta h$ 를 산출한 후 결정된다.

E. 최대 수면 강하량 $\Delta \hat{h}$

최대 수면 강하량 $\Delta \hat{h}$ 는 전절에서 산출된 된 평균 수면 강하 량 $\Delta h$ 을 활용하며 산출될 수 있으며 이를 기술하면 다음과 같다.

$$
\begin{aligned}
& \frac{\Delta \hat{h}}{\Delta h}=1+2 A_{w}^{*} \text { for } \frac{b_{w}}{L_{s}}<1.5 \\
& \frac{\Delta \hat{h}}{\Delta h}=1+4 A_{w}{ }^{*} \text { for } \frac{b_{w}}{L_{s}} \geq 1.5 \\
& A_{w}^{*}=\frac{y_{s} h}{A_{c}}
\end{aligned}
$$

여기서, $y_{s}$ 는 수로 하안에서 선박의 중심까지의 이격거리, $L_{s}$ 는 선박의 길이를 각각 나타낸다 (Fig. 5 참조).

F. 선수파 파고 $\Delta h_{f}$ 와 선수파 파형경사 $i_{f}$

선수파 (front wave) 파고 $\Delta h_{f}$ 는 전절에서 산출된 평균 수 면 강하량 $\Delta h$ 과 최대 수면 강하량 $\Delta \hat{h}$ 로부터 다음과 같이 산출되며

$$
\Delta h_{f}=0.1 \Delta h+\Delta \hat{h}
$$

선수파 파형경사 $i_{f}$ 는 다음과 같이 기술된다.

$$
i_{f}=0.03 \Delta h_{f}
$$

G. 선미파 파고 $z_{\max }$ 와 선미파 파형 경사 $i_{\max }$

선미파 (stern wave) 파고 $z_{\max }$ 와 선미파 파형 경사 $i_{\max }$ 는 전절에서 산출된 최대 수면 강하량 $\Delta \hat{h}$ 으로부터 다 음과 같이 정의되며

$$
z_{\max }=1.5 \Delta \hat{h}
$$

$i_{\max }=\left(z_{\max } / z_{o}\right)^{2}$, with: $i_{\max }<0.15$ 
식 (21)에서 $z_{o}$ 는 다음과 같이 정의되며

$z_{o}=0.16 y_{s}-c_{2}$

여기서

$y_{s}=0.5 b_{w}-B_{s}-y$

$B_{s}$ 는 선박폭, $y$ 는 수로 중앙에서 선박까지의 거리, $c_{2}$ 는 0.2 에서 2.6사이의 값을 지니는 계수를 나타낸다 (Fig. 5 참조).

\section{4. 기본방정식}

\section{1 동수역학 모형}

기본방정식으로는 가장 강건한 동수역학모형인 Navier Stokes 식과 질량보존식을 사용하였으며 고정 계산망에서 고 형물의 기하학적 특성을 기술하기 위한 부분면적계수 $A_{f}$ 와 부분체적계수 $V_{f}$ 를 활용하여 이를 기술하면 다음과 같다.

$$
\begin{aligned}
& \frac{V_{f}}{\rho c^{2}} \frac{\partial p}{\partial t}+\frac{\partial}{\partial x}\left(u A_{x}\right)+\frac{\partial}{\partial y}\left(v A_{y}\right)+\frac{\partial}{\partial z}\left(w A_{z}\right)=0 \\
& \frac{\partial u}{\partial t}+\frac{1}{V_{F}}\left\{u A_{x} \frac{\partial u}{\partial x}+v A_{y} \frac{\partial u}{\partial y}+w A_{z} \frac{\partial u}{\partial z}\right\}=-\frac{1}{\rho} \frac{\partial p}{\partial x}+G_{x}+f_{x} \\
& \frac{\partial v}{\partial t}+\frac{1}{V_{F}}\left\{u A_{x} \frac{\partial v}{\partial x}+v A_{y} \frac{\partial v}{\partial y}+w A_{z} \frac{\partial v}{\partial z}\right\}=-\frac{1}{\rho} \frac{\partial p}{\partial y}+G_{y}+f_{y} \\
& \frac{\partial w}{\partial t}+\frac{1}{V_{F}}\left\{u A_{x} \frac{\partial w}{\partial x}+v A_{y} \frac{\partial w}{\partial y}+w A_{z} \frac{\partial w}{\partial z}\right\}=-\frac{1}{\rho} \frac{\partial p}{\partial z}+G_{z}+f_{z}
\end{aligned}
$$

여기서 $\rho$ 는 밀도, $u, v, w$ 는 방향 유속성분, $p$ 는 압력, $\vec{G}=[0,0,-9.8]$ 는 중력가속도를 각각 나타낸다. 식 (25), (26) (27)에서의 $f_{x}, f_{y}, f_{z}$ 는 각각 다음과 같이 정의되며

$$
\begin{aligned}
& \rho V_{F} f_{x}=\tau_{b x}-\left\{\frac{\partial}{\partial x}\left(A_{x} \tau_{x x}\right)+\frac{\partial}{\partial y}\left(A_{y} \tau_{x y}\right)+\frac{\partial}{\partial z}\left(A_{z} \tau_{x z}\right)\right\} \\
& \rho V_{F} f_{y}=\tau_{b y}-\left\{\frac{\partial}{\partial x}\left(A_{x} \tau_{x y}\right)+\frac{\partial}{\partial y}\left(A_{y} \tau_{y y}\right)+\frac{\partial}{\partial z}\left(A_{z} \tau_{y z}\right)\right\} \\
& \rho V_{F} f_{z}=\tau_{b z}-\left\{\frac{\partial}{\partial x}\left(A_{x} \tau_{x z}\right)+\frac{\partial}{\partial y}\left(A_{y} \tau_{y z}\right)+\frac{\partial}{\partial z}\left(A_{z} \tau_{z z}\right)\right\}
\end{aligned}
$$

$\tau_{b i}[i=x, y, z]$ 는 저면전단응력을 나나내며, 전단응력 $\tau_{i j}$ 는 삼차원 평면 $[i, j=x, y, z]$ 에서 다음과 같이 기술될 수 있다.

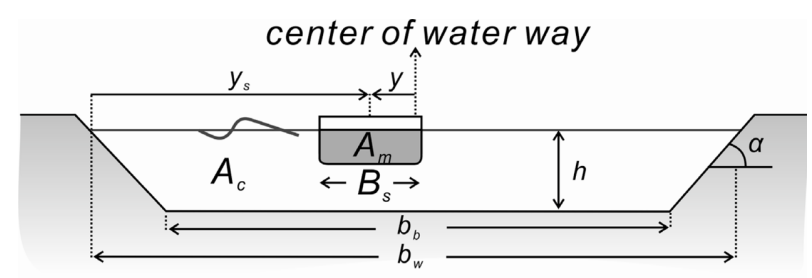

Fig. 5. Definition sketch of the parameters required to characterize the water channel and a ship.

$$
\begin{aligned}
& \tau_{x x}=-2 \mu\left\{\frac{\partial u}{\partial x}-\frac{1}{3}\left(\frac{\partial u}{\partial x}+\frac{\partial v}{\partial y}+\frac{\partial w}{\partial z}\right)\right\} \\
& \tau_{y y}=-2 \mu\left\{\frac{\partial v}{\partial y}-\frac{1}{3}\left(\frac{\partial u}{\partial x}+\frac{\partial v}{\partial y}+\frac{\partial w}{\partial z}\right)\right\} \\
& \tau_{z z}=-2 \mu\left\{\frac{\partial w}{\partial z}-\frac{1}{3}\left(\frac{\partial u}{\partial x}+\frac{\partial v}{\partial y}+\frac{\partial w}{\partial z}\right)\right\} \\
& \tau_{x y}=-\mu\left\{\frac{\partial v}{\partial x}+\frac{\partial u}{\partial y}\right\} \\
& \tau_{x z}=-\mu\left\{\frac{\partial u}{\partial z}+\frac{\partial w}{\partial x}\right\} \\
& \tau_{y z}=-\mu\left\{\frac{\partial v}{\partial z}+\frac{\partial w}{\partial y}\right\}
\end{aligned}
$$

식 (31) (36)에서 동점성계수 $\mu$ 는 난류 점성계수 $v_{T}$ 와 점 성계수 $v$ 의 화로 다음과 같이 해석되며

$$
\mu=\rho\left(v_{T}+v\right)
$$

난류특성 속도와 특성길이 $L_{t}$ 에 의해 결정되는 난류 점성 계수 $v_{T}$ 는 다음과 같이 정의된다.

$$
v_{T}=C_{1} \frac{q^{2}}{D}
$$

여기서 계수 $\mathrm{C}_{1}$ 은 가장 보편적 난류모형인 $k-\varepsilon$ 모형에서 는 0.09 , RNG (Renormalization-Group) 모형에서는 0.85 의 값을 지니며 난류에너지 소산률 $\varepsilon$ 는 난류 운동에너지 $k$ 와 특성길이 $L_{t}$ 로 기술하는 경우 다음과 같이 기술될 수 있다.

$$
\varepsilon=C_{1} \sqrt{\frac{3}{2}} \frac{k^{3 / 2}}{L_{t}}
$$

국지적 난류의 생성, 이송, 확산과정으로 인한 유동계 내 난 류 점성계수 $v_{T}$ 의 변화는 난류에너지 $k$, 소산률 $\varepsilon$ 에 대한 이송방정식을 차용하여 설명하였으며 이를 기술하는 경우 다 음과 같다.

$$
\begin{gathered}
\frac{\partial k}{\partial t}+\frac{1}{V_{F}}\left\{u A_{x} \frac{\partial k}{\partial x}+v A_{y} \frac{\partial k}{\partial y}+w A_{z} \frac{\partial k}{\partial z}\right\}=P+G+D_{k}-\varepsilon \\
\frac{\partial \varepsilon}{\partial t}+\frac{1}{V_{F}}\left\{u A_{x} \frac{\partial \varepsilon}{\partial x}+v A_{y} \frac{\partial \varepsilon}{\partial y}+w A_{z} \frac{\partial \varepsilon}{\partial z}\right\} \\
=\frac{C_{D 1} \varepsilon}{k}\left(P+C_{D 3} G\right)+D_{\varepsilon}-C_{D 2} \frac{\varepsilon^{2}}{k}
\end{gathered}
$$

식 (40), (41)에서 $P, G, D_{k}$ 는 각각 전단력에 의한 난류에 너지의 생성, 부력에 의한 난류에너지의 생성, 난류에너지의 확산을 나타내며 다음과 같이 정의되며

$$
P=C_{\text {shear }}\left(\frac{\mu}{\rho V_{F}}\right)\left[2 A_{x}\left(\frac{\partial u}{\partial x}\right)^{2}+2 A_{y}\left(\frac{\partial v}{\partial y}\right)^{2}+2 A_{z}\left(\frac{\partial w}{\partial z}\right)^{2}\right.
$$




$$
\begin{aligned}
& +\left(\frac{\partial v}{\partial x}+\frac{\partial u}{\partial y}\right)\left(A_{x} \frac{\partial v}{\partial x}+A_{y} \frac{\partial u}{\partial y}\right)+\left(\frac{\partial u}{\partial z}+\frac{\partial w}{\partial x}\right)\left(A_{z} \frac{\partial u}{\partial z}+A_{x} \frac{\partial w}{\partial x}\right) \\
& \left.+\left(\frac{\partial v}{\partial z}+\frac{\partial w}{\partial y}\right)\left(A_{z} \frac{\partial v}{\partial z}+A_{y} \frac{\partial w}{\partial y}\right)\right] \\
& G=-C_{G}\left(\frac{\mu}{\rho}\right)\left(\frac{\partial \rho}{\partial x} \frac{\partial p}{\partial x}+\frac{\partial \rho}{\partial y} \frac{\partial p}{\partial y}+\frac{\partial \rho}{\partial z} \frac{\partial p}{\partial z}\right) \\
& D_{k}=\frac{1}{V_{F}}\left\{\frac{\partial}{\partial x}\left(v_{k} A_{x} \frac{\partial k}{\partial x}\right)+\frac{\partial}{\partial y}\left(v_{k} A_{y} \frac{\partial k}{\partial y}\right)+\frac{\partial}{\partial z}\left(v_{k} A_{z} \frac{\partial k}{\partial z}\right)\right\} \\
& D_{\varepsilon}=\frac{1}{V_{F}}\left\{\frac{\partial}{\partial x}\left(v_{\varepsilon} A_{x} \frac{\partial \varepsilon}{\partial x}\right)+\frac{\partial}{\partial y}\left(v_{\varepsilon} A_{y} \frac{\partial \varepsilon}{\partial y}\right)+\frac{\partial}{\partial z}\left(v_{\varepsilon} A_{z} \frac{\partial \varepsilon}{\partial z}\right)\right\}
\end{aligned}
$$

여기서 $C_{\text {shear }}, C_{G}, v_{k}, v_{\varepsilon}$ 는 다음과 같이 정의될 수 있다.

$$
C_{\text {shear }}, C_{G}, v_{k}, v_{\varepsilon}=C_{i}\left(\frac{\mu}{\rho}\right)
$$

식 (41)에서 $C_{D 1}, C_{D 2}, C_{D 3}$ 는 계수이나 RNG (RenormalizationGroup) 모형에서 $C_{D 3}$ 는 전단변형률에 종속한다. 전술한 난 류에너지 $k$, 소산률 $\varepsilon$ 이송방정식 해석을 위한 경계조건은 국지적으로 난류생성과 소멸간에 균형을 이룬다는 가정을 토 대로 다음과 같이 산출된다.

$$
\begin{aligned}
& k=\frac{u_{*}^{2}}{\sqrt{C_{1}}} \\
& \varepsilon=\frac{u_{*}^{3}}{(k d)}
\end{aligned}
$$

여기서 $u *$ 는 전단속도로 다음과 같은 대수 유속분포로부터 산출된다.

$$
u=u_{*}\left[\frac{1}{k} \ln \left(\frac{\rho u_{*} d}{\mu}\right)+5.0\right]
$$

자유수면 또는 유체와 물체간의 경계면 추적을 위해 유체 체적법(VOF, Volume of Fluid) 방법이 사용되며 복잡다기한 경계면 기술을 위해서는 FAVOR 방법을 사용하였다. 유체 체 적법(VOF, Volume of Fluid)에서 자유수면은 격자내의 유체점 유율(Fluid fraction)과 주위 격자와의 관계로부터 산출되며, $\mathrm{VOF}$ 방정식은 다음과 같이 기술될 수 있다.

$$
\frac{\partial F}{\partial t}+\left\{\frac{\partial}{\partial x}\left(F u A_{x}\right)+\frac{\partial}{\partial y}\left(F v A_{y}\right)+\frac{\partial}{\partial z}\left(F w A_{z}\right)\right\}=F_{D I F}
$$

여기서 $F_{D I F}$ 는 diffusion of fluid fraction으로 다음과 같이 나타낼 수 있다.

$$
F_{D I F}=\frac{1}{V_{F}}\left\{\frac{\partial}{\partial x}\left(v_{F} A_{x} \frac{\partial F}{\partial x}\right)+\frac{\partial}{\partial y}\left(v_{F} A_{x} \frac{\partial F}{\partial y}\right)+\frac{\partial}{\partial z}\left(v_{F} A_{x} \frac{\partial F}{\partial z}\right)\right\}
$$

여기서 $\mathrm{F}$ 는 유체점유율로 유체내에서는 일의 값을 지니며 그 렇지 못한 경우 영의 값으로 수렴된다. 자유수면을 지니는 검
사체적에서 평균을 취하는 경우 유체점유율은 영과 일 사이 의 값을 지니며 계산격자를 통해 유체가 유동하는 경우 시공 을 통해 상이한 값을 지니게 된다. 식 (51)에서의 확산계수 $v_{F}$ 는 다음과 같이 정의되며

$$
v_{F}=c_{F} \frac{\mu}{p}
$$

여기서 계수 $c_{F}$ 는 turbulent Schmidt number의 역수로 정 의된다.

\section{5. 수치모형의 검증}

전술한 수치모형과 폭이 좁은 수로에서는 고립파 형태의 항 주파가 생성된다는 가설을 검증하기 위해 협수로에서의 항주 파 생성과정에 대한 총 다섯 번의 수치 모의를 수행하였다. 수 치모의는 우리나라에서 기 운영 중인 인공수로의 수로단면을 고려하여 경사하안을 지니는 수로 [test channel 1]와, 직립하 안으로 구성된 수로 [test channel 2]에서 전장(長), 폭(幅), 만 재흘수가 각각 $158.02 \mathrm{~m} \times 16.0 \mathrm{~m} \times 5.2 \mathrm{~m}$ 인 유람선과, $66 \mathrm{~m}$ $\times 13.8 \mathrm{~m} \times 3.2 \mathrm{~m}$ 인 수상버스를 대상으로 수행되었으며, 우리나 라에서 기 운영 중인 인공수로의 수리조건을 고려하여 수심은 test channel 1, 2에서각각 $7 \mathrm{~m}$ 와 $5 \mathrm{~m}$ 로 선정하였다 (Fig. 6 참 조). RUN 1, 2, 3, 4에 사용된 Test channel 1의 제원은 $b_{b}=80 \mathrm{~m}, b_{w}=124 \mathrm{~m}, \cot \alpha=22 / 7, A_{c}=714 \mathrm{~m}^{2}$ 이며, 선 속에 따른 항주파 특성변화를 파악하기 위해 선속은 10.69 , 8.74, 6.8, 4.8 knots로 조절하였다 (Fig. 6 참조). Tabel 1에

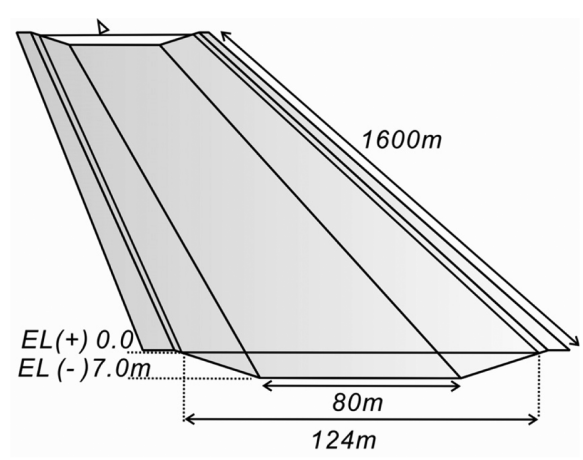

(a) test channel 1

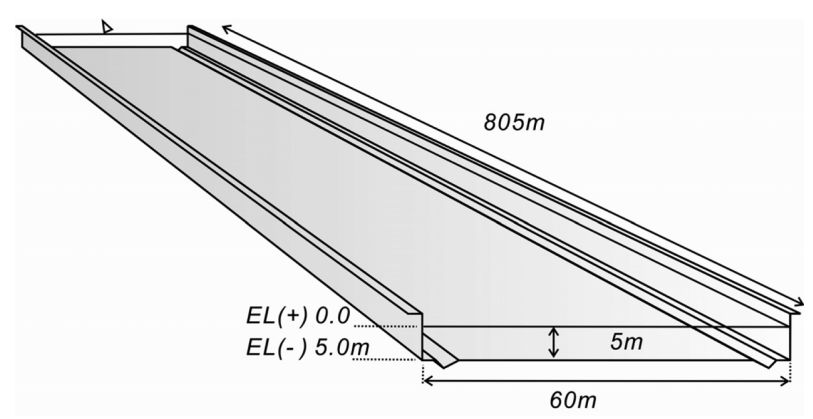

(b) test channel 2

Fig. 6. Layout of test channel. 
Table 1. Summary of hydraulic condition used in the numerical simulation for the verification

\begin{tabular}{lcc}
\hline \hline & ship type and its velocity & water channel type \\
\hline RUN 1 & cruise, 10.69 knots $[5.5 \mathrm{~m} / \mathrm{s}]$ & test channel 1 \\
RUN 2 & cruise, 8.74 knots $[4.5 \mathrm{~m} / \mathrm{s}]$ & test channel 1 \\
RUN 3 & cruise, 6.8 knots $[3.5 \mathrm{~m} / \mathrm{s}]$ & test channel 1 \\
RUN 4 & cruise, 4.8 knots $[2.5 \mathrm{~m} / \mathrm{s}]$ & test channel 1 \\
RUN 5 & water bus, 9.5 knots $[4.8 \mathrm{~m} / \mathrm{s}]$ & test channel 2 \\
\hline
\end{tabular}

는 각 수치 모의에 사용된 선박의 종류와 선속, 수로 형식을 정리하였다.

선박은 수로중앙을 일정한 속도로 운항하는 것으로 가정하 였으며, Fig. 7에는 RUN 1, 2, 3, 4에서 선박 통과시 수로 중앙에서 관측되는 수면 변위 시계열 자료를 도시하였다. Fig. 8 에는 RUN 1, 2, 3, 4에서 수치모의 된 선수파 파고를 선속 별로 도시하였으며, 비교를 위해 Eq. (8)에 정의된 해석모형 과 PIANC 모형에 기초하여 산출된 선수파 파고도 함께 도 시하였다. 이 과정에서 2.2절에서 정의한 항주파 파고 $\eta$ 는 PIANC (1987)에 정의하는 선수파 (front wave) 파고 $\Delta h_{f}$ 로 다음과 같이 환산하였다 (Fig. 1 참조).

$$
\Delta h_{f}=\eta+\text { 흘수 }
$$

선속이 증가함에 따라 선수파 파고는 증가하는 것을 알 수 있다 (Fig. 7 참조). PIANC 모형은 $V_{s}=10.69,8.74$ knots 인 경우, 식 (12)을 충족하는 선수파 파고가 존재하지 않았 다. 또한 $V_{s}=6.8,4.8 \mathrm{knots}$ 경우, PIANC 모형은 수치 모 의보다 상당히 낮은 수치를 제공한다(Fig. 8 참조).

이러한 현상은 PIANC 모형이 개방된 해역을 대상으로 개 발되어, 우리나라 인공운하에서 흔히 관측되는 협수로에 적 용하는 경우 하안에서 진행되는 반사가 간과되어 오류가 야
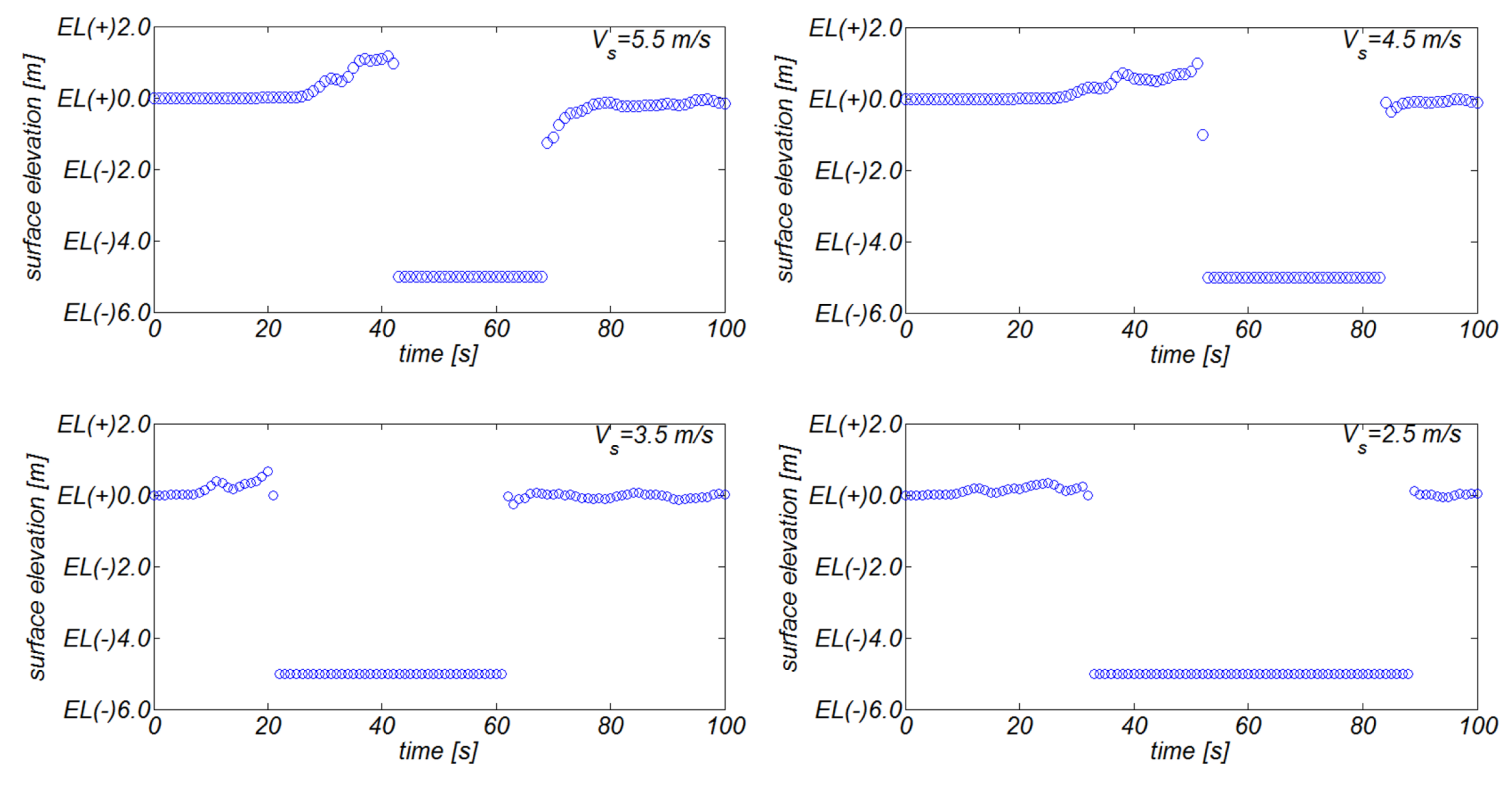

Fig. 7. Numerically simulated free water surface elevation as the ship of varying velocity are navigating along the center of waterway $[$ Draft $=5.2 \mathrm{~m}]$.

기될 수 있음을 시사한다.

Eq. (8)에 기술된 해석모형은 $V_{s}=10.69,8.74$ knots의 경 우, 수치모의결과를 $10 \sim 15 \%$ 상회하는 수치를 제공하나, 선 속이 감속되면 전술한 오차는 급격하게 작아졌다. 이러한 차 이는 해석모형의 유도과정에 수행된 이상유체라는 가정과 선 박 선수부의 곡면을 평면으로 가정한 점을 상기하면 수용 가 능한 수치로 보인다. 따라서 수치모의가 불가한 경우 보수적 인 항주파 산출과정에 활용되면 유용한 정보를 제공할 수 있 다고 판단된다.

Fig. 9에는 RUN 5에서 수로 하류에서 $[x=429,529$, $629 \mathrm{~m}$ ] 관측된 수면 변위 시계열 자료를 도시하였다. 협수로 에서는 고립파 형태의 항주파가 생성된다는 본고의 가설과 일 치하는 고립파 형태의 항주파가 생성되는 것을 확인 할 수 있 다. 선박 전면수역에 생성된 고립파는 $8 \mathrm{~m} / \mathrm{s}$ 의 속도로 진행 되는 것으로 모의되었으며, 이러한 수치는 고립파 파속으로 알려진 $\sqrt{g(h+A)}=7.77 \mathrm{~m} / \mathrm{s}$ 에 부합한다. 또한 양안에서 진 행되는 반사로 선박 전연수역에 상당한 요동이 상당 기간 지 속되는 것을 확인할 수 있다 (Fig. 10 참조).

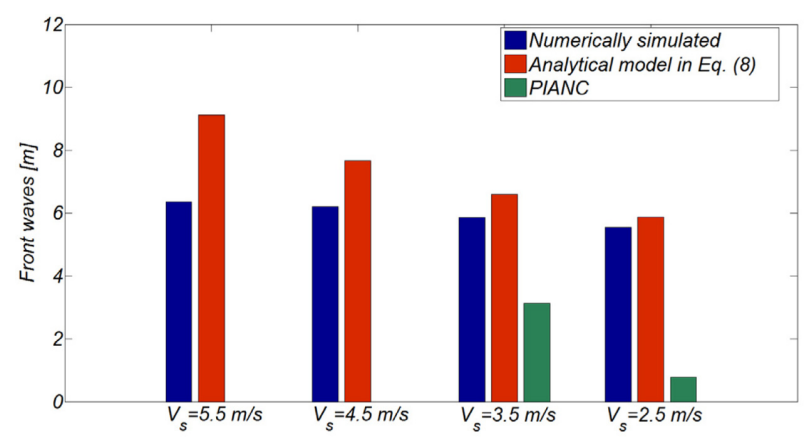

Fig. 8. Comparison of numerically simulated front wave height with the ones based on the analytical model in Eq. (8) and the PIANC [draft $=5.2 \mathrm{~m}$ ].

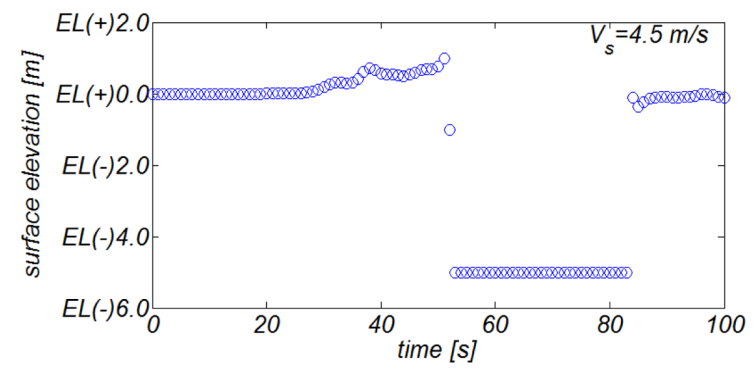




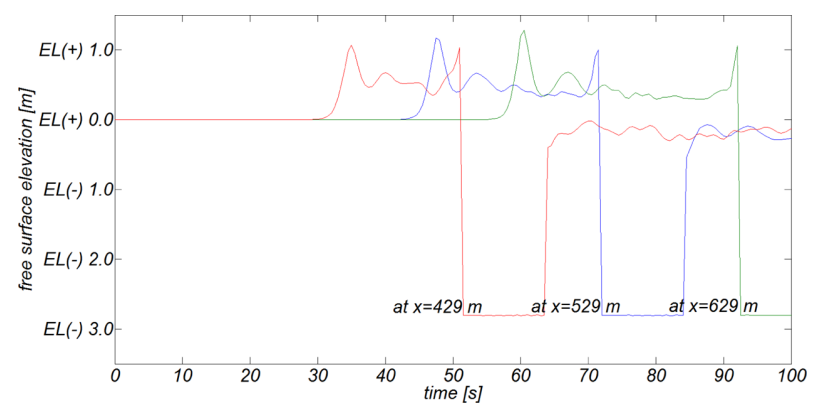

Fig. 9. Time series of numerically simulated water surface elevation at $\mathrm{x}=429,529,629 \mathrm{~m}$ as the ship are navigating along the center of waterway [RUN 5].

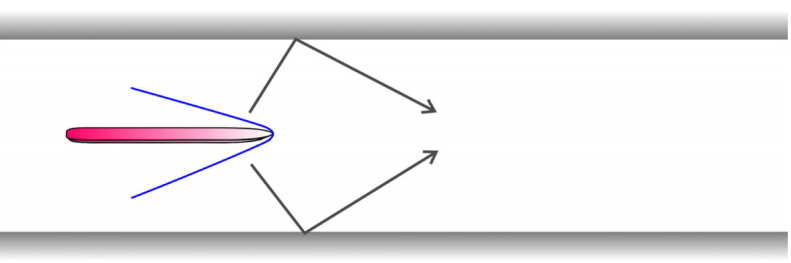

Fig. 10. Definition sketch of driving mechanism of intensified front waves.

\section{6. 수치모의}

현재 검토가 진행 중인 송도 운하에 담겨있는 수로를 대상 으로 선박의 협수로 통과시 생성되는 고립파 특성과, 고립파 제어를 위해 요구되는 선박의 적정 선속을 결정하기 위해 수 치모의를 수행하였다. 수치모형은 가장 정교한 동수역학 모형 인 삼차원 Navier Stokes 식과 VOF에 기초하여 구성하였다. 수치 모의는 전장(長), 폭(幅), 만재흘수가 각각 $66.0 \mathrm{~m} \times 13.8 \mathrm{~m}$ $\times 3.18 \mathrm{~m}$ 인 유람선과 $29.0 \mathrm{~m} \times 7.0 \mathrm{~m} \times 1.45 \mathrm{~m}$ 인 수상 버스를 대상으로 수행되었으며, 유람선과 수상버스의 선속은 각각 $9.5 \mathrm{knots}, 6.7 \mathrm{knots}$ 로 선정하였다. 유람선은 수로 NO. 1, 2, 3 , 수상 버스는 수로 NO. 4,5 를 각각 운항하며 수위는 운영 수위인 $\mathrm{EL}+1.0 \mathrm{~m}$ 로 취하였다.

\section{1 계산영역 및 수면변위 계측점 위치}

Fig. 11에는 본고에서 다루는 송도운하를 도시하였으며, 항 주파 수치모의에 활용된 계산영역도 Fig. 11에 함께 수록하 였다. 도시된 각 계산 영역은 4,250,000만개의 절점을 활용 하여 이산화 하였다.

\section{2 수치결과}

\subsection{1 남측 수로[NO 1]}

Fig. 12, 13에는 수치모의된 자유수면 snapshots과 유속 등 고선도, 하안 인근에서 관측된 자유수면 시계열도를 각각 도 시하였다. 선수파 $0.46 \mathrm{~m}$, 선미파 $0.3 \mathrm{~m}$ 내외로 관측된다. 또 한 초기선도 파봉에 후행한 파봉이 상대적으로 크며 이는 하 안에서 진행된 반사에 기인한 것으로 보이며 이십초 이상의 긴 주기를 지닌 것으로 관측된다.

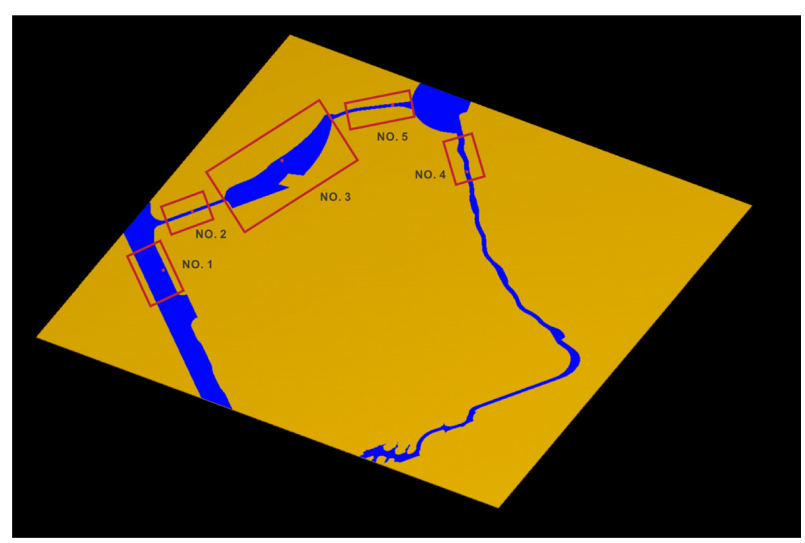

Fig. 11. Layout of the hypothetical canal used in this study, computational domain, and locations of data acquisition points in each of the 5 sub water channels comprising the hypothetical canal.

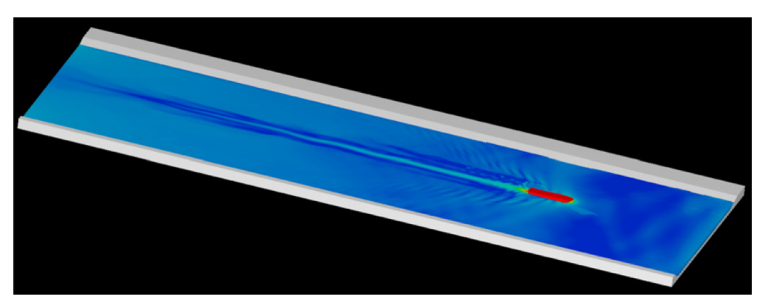

Fig. 12. Bird's eye plot of numerically simulated free water surface field and contour plot of flow velocity induced by ship movement.

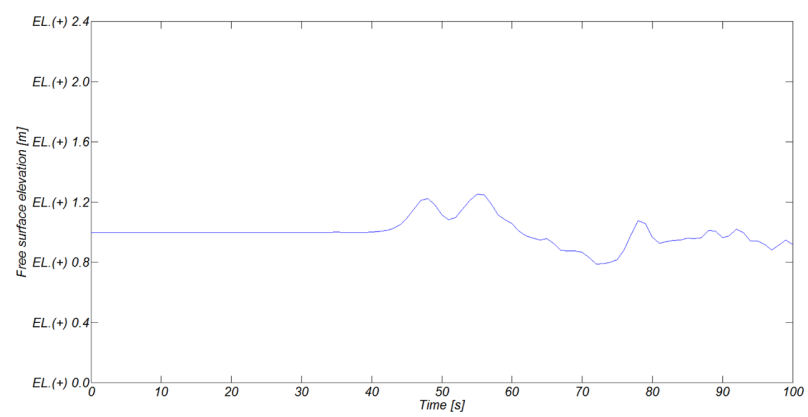

Fig. 13. Time series of numerically simulated free water surface measured near the bank of water channel.

\subsection{2 연결수로 유입부[NO 2]}

Fig. 14, 15(a), 15(b)에는 수치모의된 자유수면 snapshots 과 유속 등고선도, 수로 출구와 수로 중앙부 하안 인근에서 관측된 자유수면 시계열도를 각각 도시하였다. 선수파 $1.82 \mathrm{~m}$, 선미파 $0.81 \mathrm{~m}$ 내외로 관측된다. 더 좁아진 수로폭 으로 인해 선도 파랑은 빠르게 하안에 도달하였으며, 이로 인해 파형은 남측 수로[NO 1]에 비해 더욱 응집된 형태를 보인다. 선도 파봉에 비해 후행 파봉이 상대적으로 작았으 나, 수로 출구에 접근 할수록 후행 파봉의 크기는 증가하였 으며 지속시간도 증가하였다 (Fig. 15(a), 15(b) 참조). 이러 한 현상은 양안에서 진행되는 반사로 파랑에너지가 집중되 어 발생하는 것으로 보이며 수로출구 인근에서는 잘 발달된 고립파를 관측할 수 있다. 


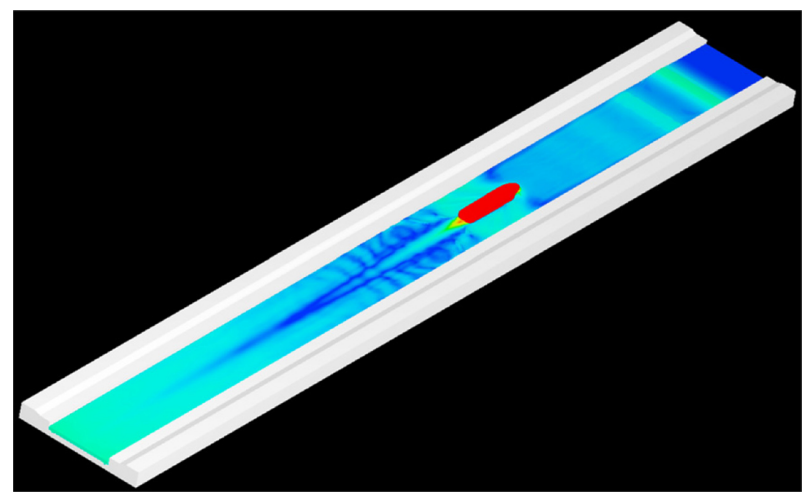

Fig. 14. Bird's eye plot of numerically simulated free water surface field and contour plot of flow velocity induced by ship movement.

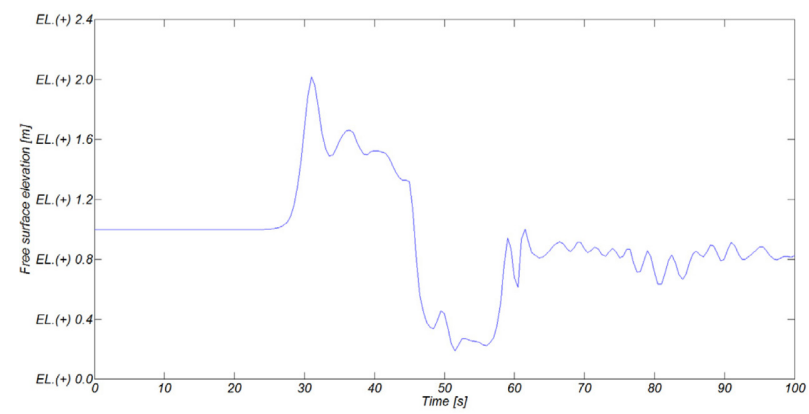

Fig. 15(a). Time series of numerically simulated free water surface measured near the bank at the center of water channel $[\mathrm{x}=398.4 \mathrm{~m}, \mathrm{y}=71.24 \mathrm{~m}]$.

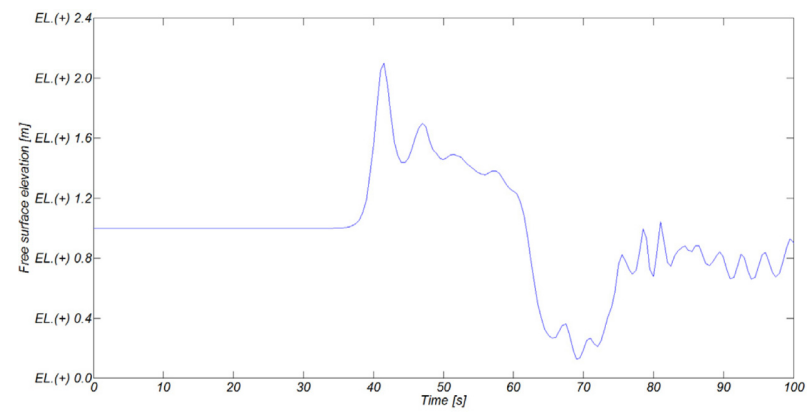

Fig. 15(b). Time series of numerically simulated free water surface measured near the bank at the exit of water channel $[x=479.28 \mathrm{~m}, \mathrm{y}=76.76 \mathrm{~m}]$.

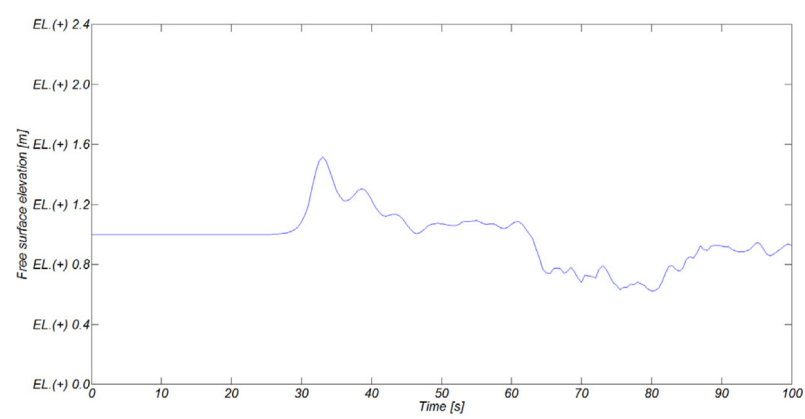

Fig. 16. Time series of numerically simulated free water surface measured near the bank at the exit of water channel $[x=398.4 \mathrm{~m}, \mathrm{y}=71.24 \mathrm{~m}$, ship velocity $3.5 \mathrm{~m} / \mathrm{s}]$.
항주파가 허용기준을 상회하는 것으로 판단되어 선속이 항 주파에 미치는 영향을 파악하기 위해 먼저, PIANC (1987)가 권하는 기준에 준하여 적정 선속을 산출하였다. 산출결과 최 대 허용선속은 $3.6 \mathrm{~m} / \mathrm{s}$ 로 산출되었다. 이어 선속을 $4.8 \mathrm{~m} / \mathrm{s}$ 에 서 $3.5 \mathrm{~m} / \mathrm{s}$ 로 감속하여 수치모의를 수행하였으며 그 결과는 Fig. 16에 도시하였다. 선수파와 선미파는 $50 \%$ 정도 감소하 였다.

\subsection{3 연결 수로 내 호수[NO 3]}

Fig. 17, 18에는 수치모의된 자유수면 snapshots과 유속 등 고선도, 하안 인근에서 관측된 자유수면 시계열도를 각각 도 시하였다. 선수파 $0.63 \mathrm{~m}$, 선미파 $0.37 \mathrm{~m}$ 내외로 관측되었다. 상대적으로 큰 수로폭으로 인해 선도 파봉과 후행 파봉은 상 당히 이격되어 관측되었다. 여기서 특이한 것은 큰 수로폭에
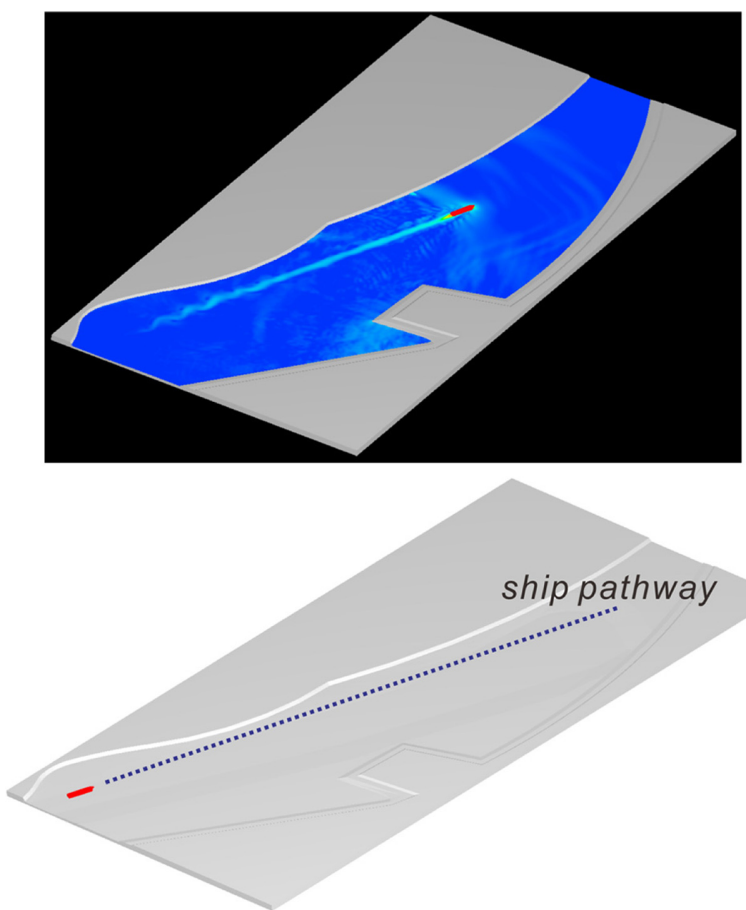

Fig. 17. Bird's eye plot of numerically simulated free water surface field and contour plot of flow velocity induced by ship movement, and the pathway of ship.

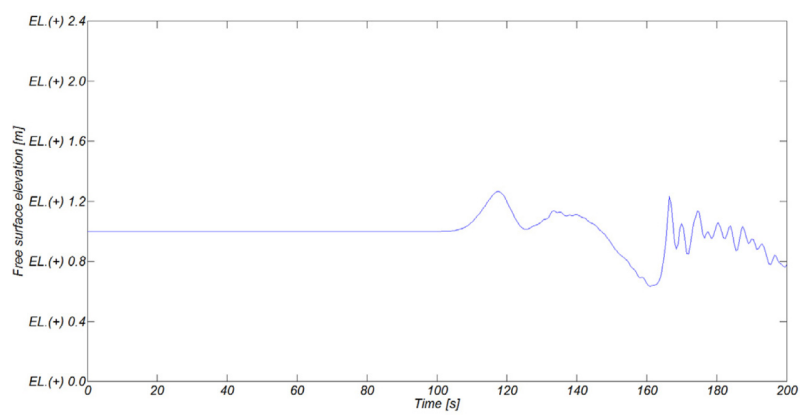

Fig. 18. Time series of numerically simulated free water surface measured near the bank of water channel. 


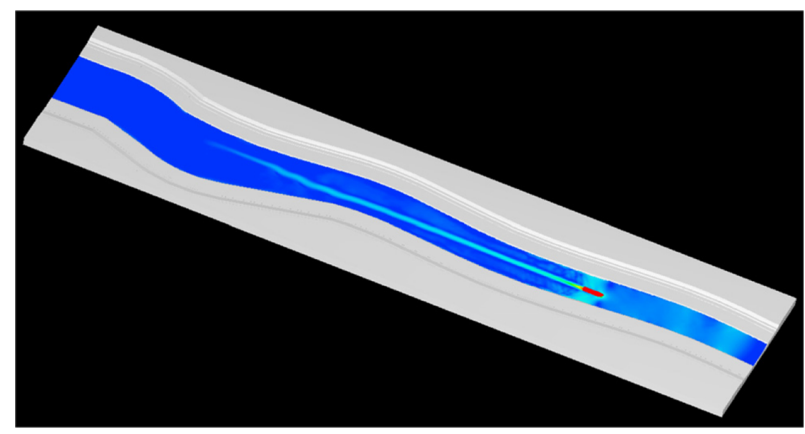

Fig. 19. Bird's eye plot of numerically simulated free water surface field and contour plot of flow velocity induced by ship movement.

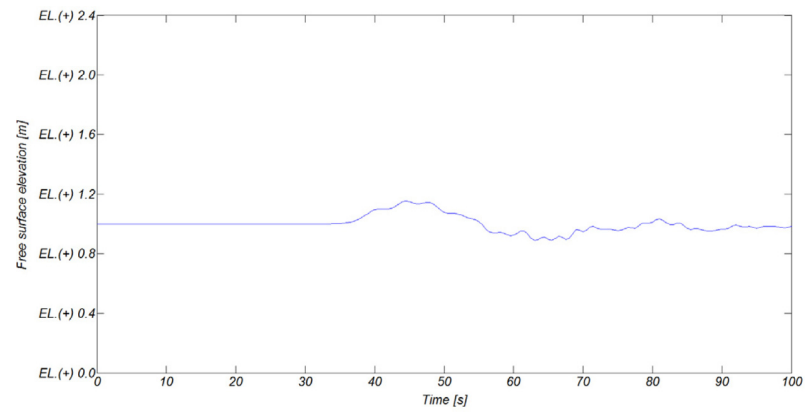

Fig. 20. Time series of numerically simulated free water surface measured near the bank of water channel.

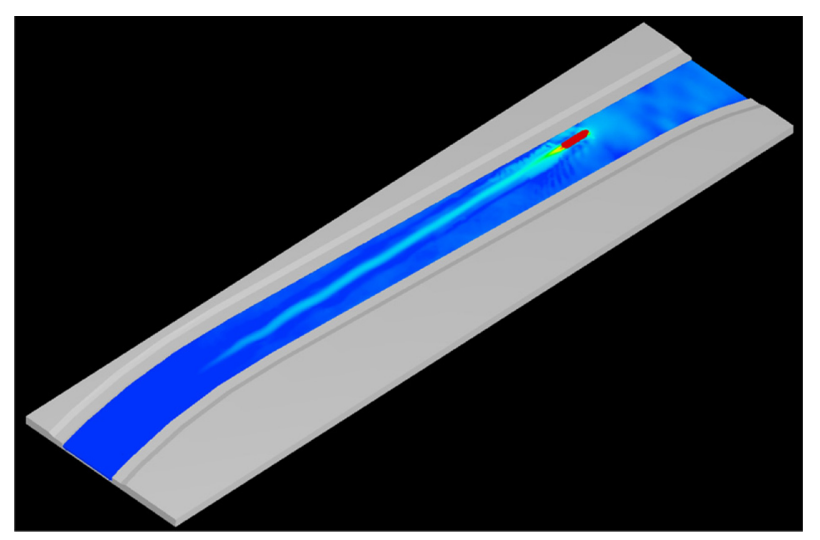

Fig. 21. Bird's eye plot of numerically simulated free water surface field and contour plot of flow velocity induced by ship movement.

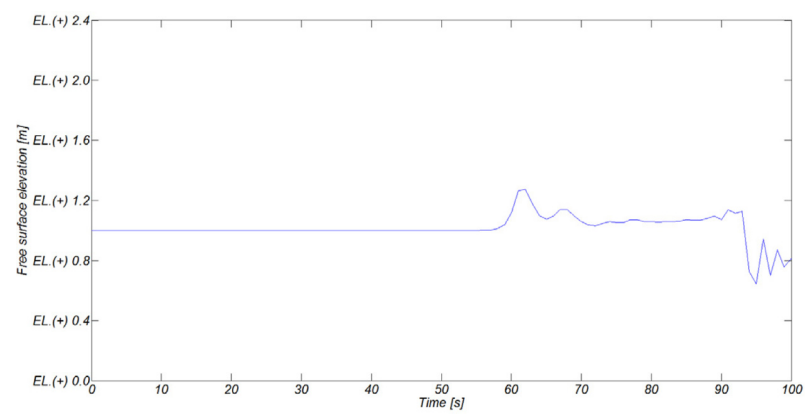

Fig. 22. Time series of numerically simulated free water surface measured near the bank of water channel.

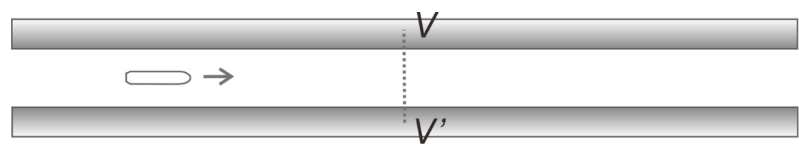

Fig. 23. Layout of water channel NO. 2 and location of data acquisition plane.

도 불구하고 선도 파형은 기 알려진 정현파의 형태가 아니라 전형적인 Solitary wave의 형태를 지닌다. 이러한 현상은 우 안 인근에 수중 거치된 고수부지로 인해 항로를 좌안에 경도 되게 조정하였고, 관측 지점이 좌안 인근이라는 점을 상기하 면 실제 수로 폭은 결과적으로 그리 넓지 않았던 것으로 판 단된다.

\subsection{4 북측수로 [NO 4]}

Fig. 19, 20에는 수치모의된 자유수면 snapshots과 유속 등고 선도, 하안 인근과 에서 관측된 자유수면 시계열도를 각각 도 시하였다. 선수파 $0.27 \mathrm{~m}$, 선미파 $0.1 \mathrm{~m}$ 내외로 관측되었다. $2.5 \mathrm{~m}$ 라는 얕은 수심과 느린 선속으로 인해 항주파의 크기는 상대적으로 작았다.

\subsection{5 연결수로2 [NO 5]}

Fig. 21, 22에는 수치모의된 자유수면 snapshots과 유속 등 고선도, 하안 인근에서 관측된 자유수면 시계열도를 각각 도 시하였다. 선수파 $0.3 \mathrm{~m}$, 선미파 $0.3 \mathrm{~m}$ 내외로 관측되었다.

\section{3 협수로에서의 항주파로 인한 수면동요 특성 - 연결수 로 NO. 2을 중심으로}

Fig. 24(a), (b), (c), (d), (e), (f), (g)에는 측점 $\mathrm{V}^{\prime} \mathrm{V}^{\prime}$ 에서 계측된 유속 벡터도를 순차적으로 도시하였다. 선박 통과전 인 86 93.5초에도 선수파로 인해 수로 전체가 상당히 동요 하는 것이 관측되며 이때 최대 유속은 $0.18 \mathrm{~m} / \mathrm{s}$ 의 값을 지 닌다[Fig. 24(a) 참조]. 선박의 선수부가 도착하는 100 초와 선 박 본체가 통과하는 104.5 109초 사이에는 유동이 양안으로 진행되는 것이 보이며 이 때 유속은 최대 $0.903 \mathrm{~m} / \mathrm{s}$ 분포하 였다 [Fig. 24(b), (c) 참조]. 이렇게 양안에 도착한 선수파는 반사로 인해 방향을 바꾸어 다시 선박쪽으로 회귀하였으며 이 때 유속은 최대 $0.628 \mathrm{~m} / \mathrm{s}$ 에 분포한다 [Fig. 24(d), (e)참조]. 이와 더불어 반사로 인한 정상파 [Standing Wave] 로 인해 수로와 선박사이에는 마디와 절이 형성되는 것을 관측할 수 있다 [Fig. 24(d), (e), (f) 참조].

선박 선미부가 빠져나간 145 초 이후에도 협수로 수괴는 선 미파로 인해 상당기간 동요가 지속되는 것을 확인 할 수 있으 며, 위치에너지와 운동에너지의 순차적인 발현과정으로 판단하 는 경우 선미파의 주기는 23 초 보인다. 이러한 수치는 PIANC (1987)에서 이야기하는 주기와는 상당부분 차이가 나는 것으로 협수로에서는 기존의 광역수로에서의 수환경을 토대로 제안된 구주의 기준식이 오류를 내포할 수 있음을 반증한다. 


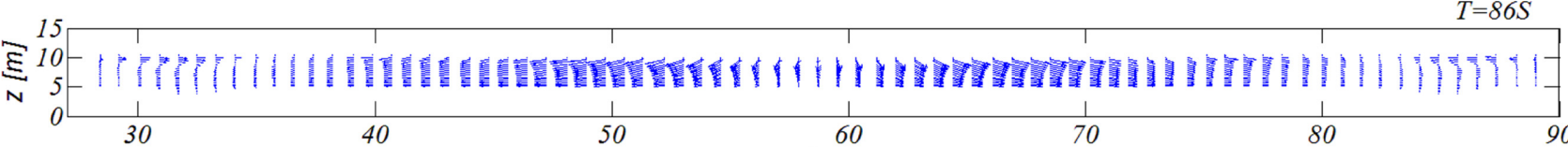
$y[m]$

$T=88.5 \mathrm{~S}$

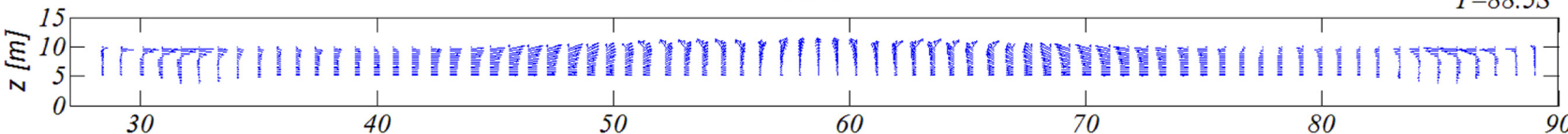

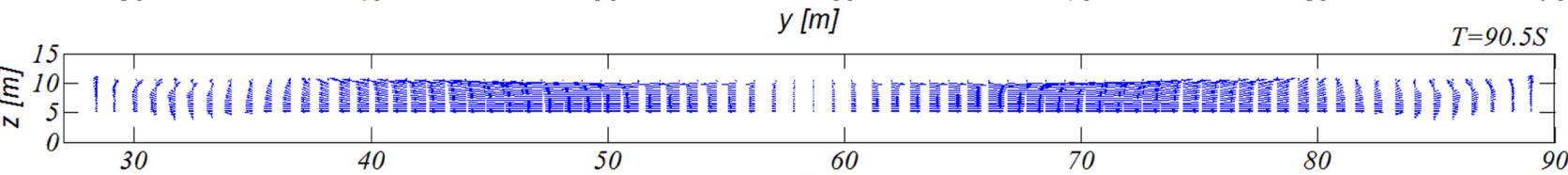

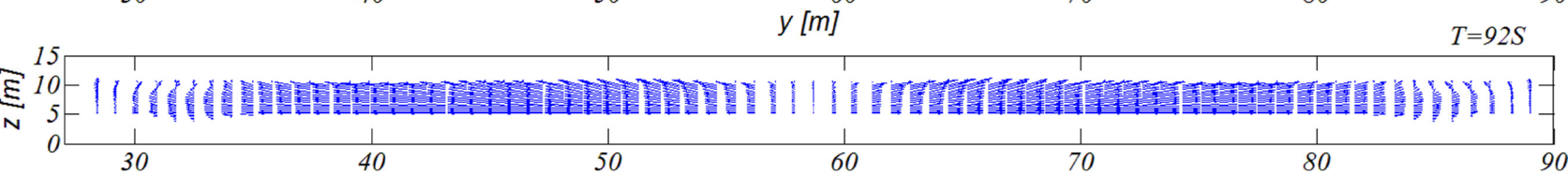

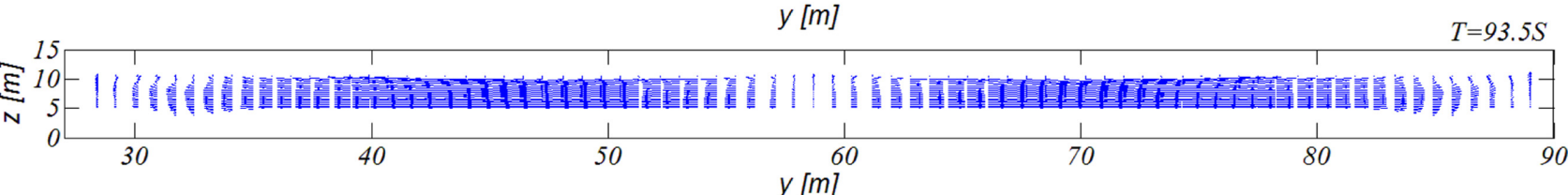

Fig. 24(a). Snapshots of water agitation in the channel due to bow waves before the ship arrives at the data acquisition point.
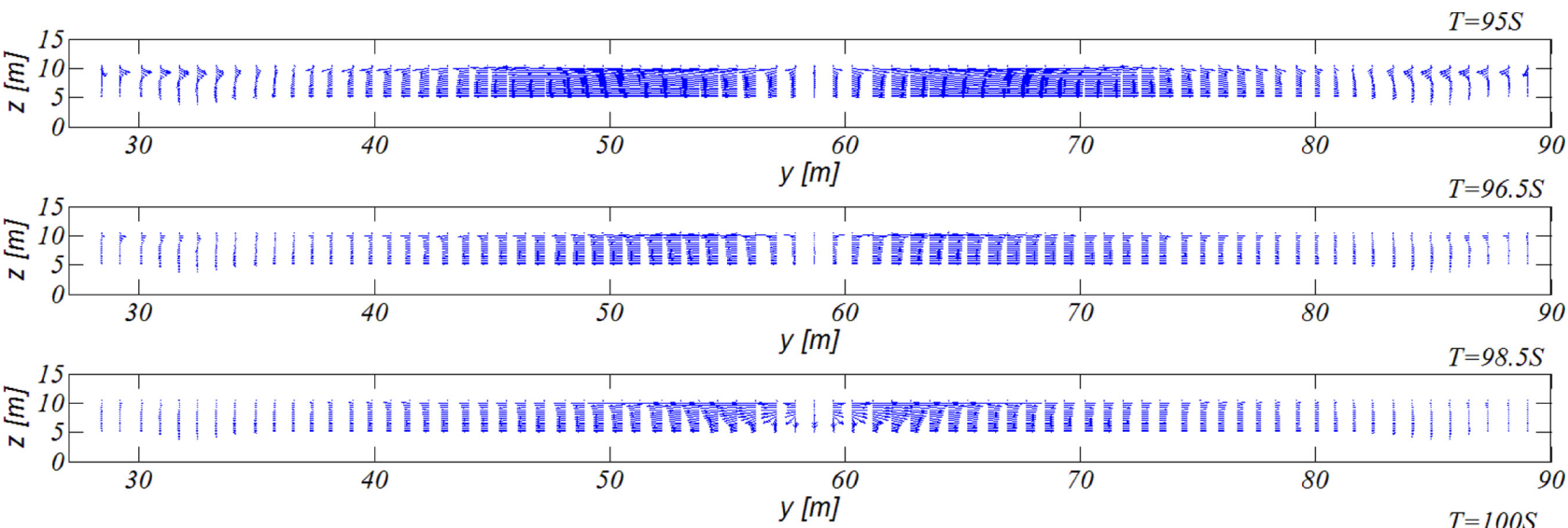

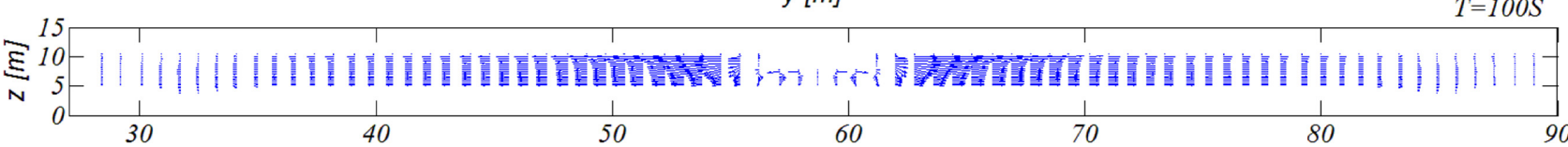

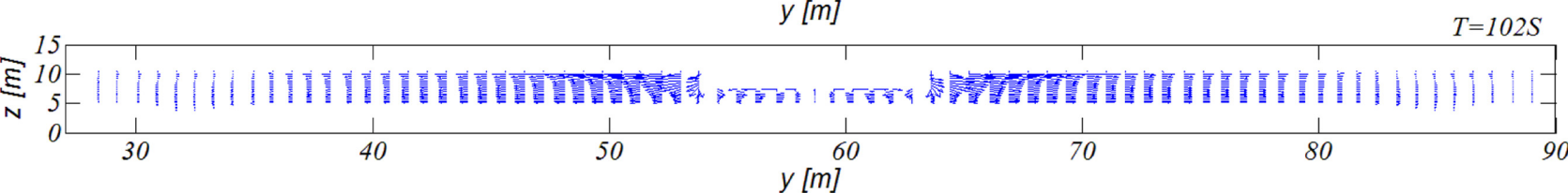

Fig. 24(b). Snapshots of water agitation in the channel just before the ship arrives at the data acquisition point and as the ship are passing through it.

\section{6. 결 론}

최근 급증한 친수공간에 대한 수요를 충족하기 위해 여러 인공운하가 검토 혹은 시공되어 운영되고 있으나, 경인 아라 뱃길처럼 예산상의 제약으로 충분한 수면적 확보에 어려움을 겪고 있는 것으로 보인다. 이러한 수환경은 자연하천과 갑문
에 기초한 구주의 운하와는 상이한 것으로, 선박 운행시 인 공운하를 구성하는 협수로에서는 상당한 크기의 고립파 형태 의 항주파가 발생할 수 있다. 이렇게 생성된 고립파는 상당 한 처오름 높이와 호안 피복석의 유실로 이어질 수 있어 상 당한 주의가 필요해 보이나, 현재 우리나라는 상대적으로 일 천한 운하 시공 및 운영 경험으로 인해 운하를 주행하는 선 


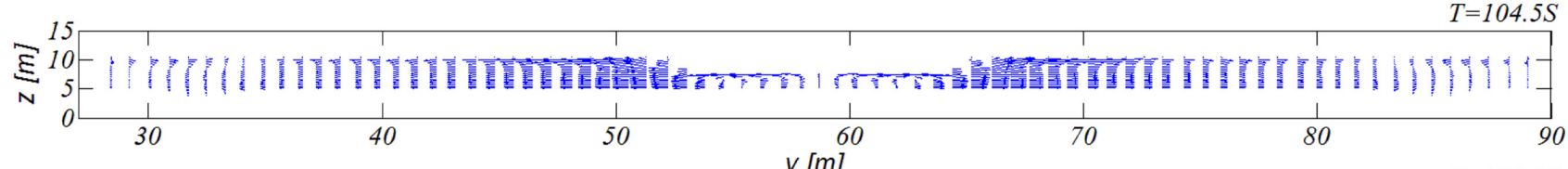

$y[\mathrm{~m}] \quad T=106.5 \mathrm{~S}$

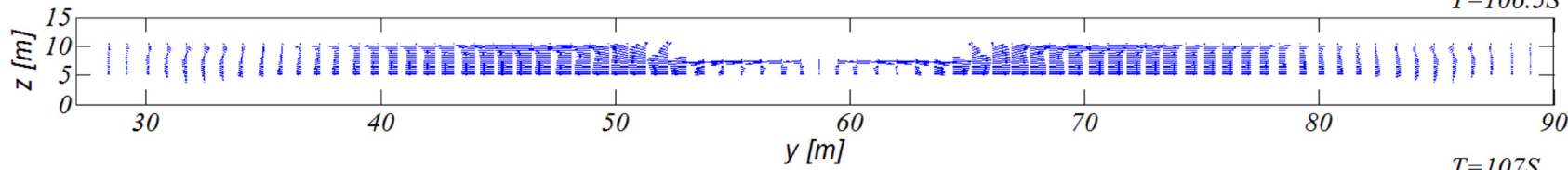

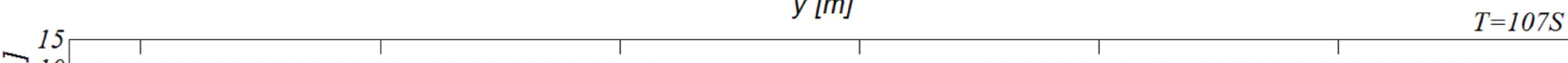

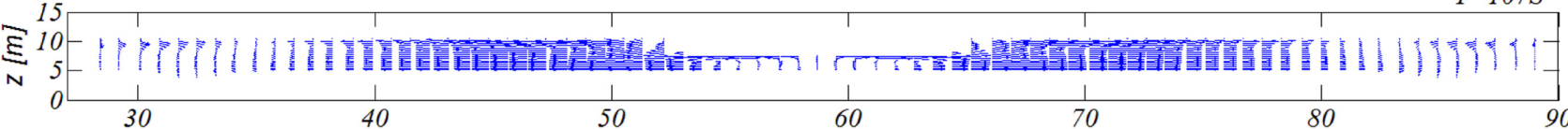

$y[\mathrm{~m}] \quad T=108 \mathrm{~S}$

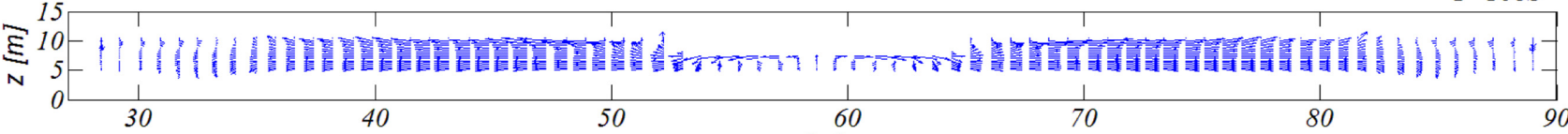

$y[\mathrm{~m}]$

$T=109 \mathrm{~S}$

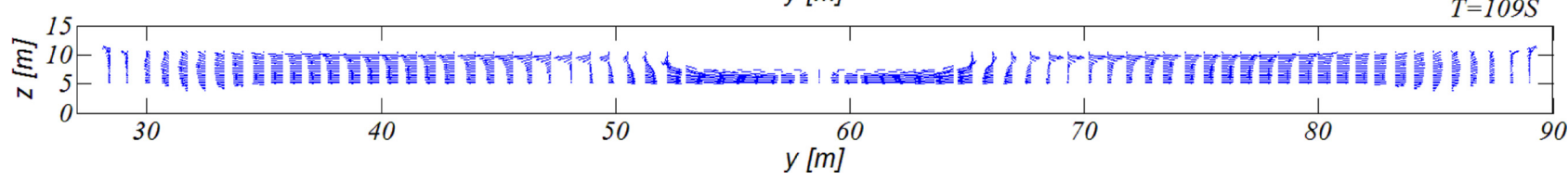

Fig. 24(c). Snapshots of water agitation in the channel as the ship are passing through the data acquisition point.

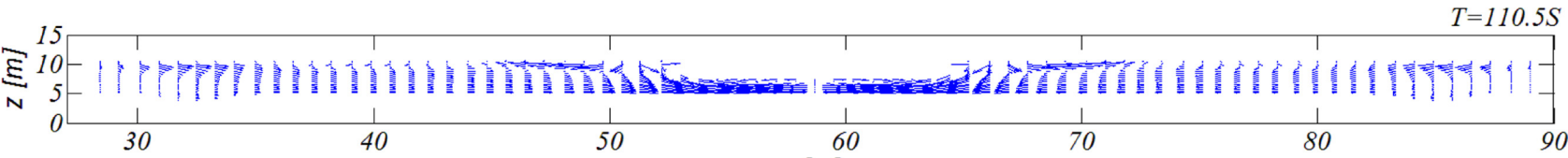

$y$ [m]

$T=111.5 \mathrm{~S}$

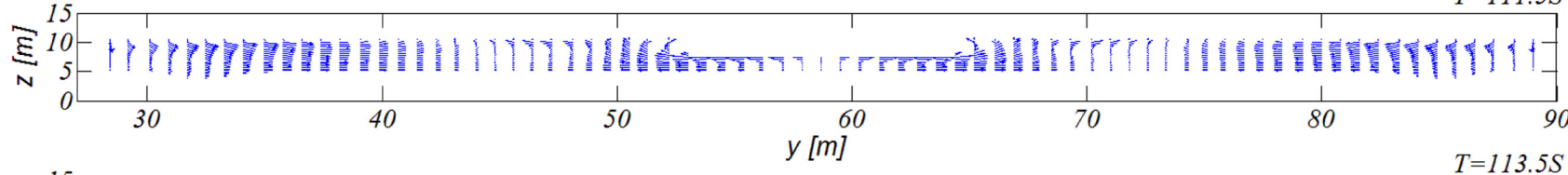

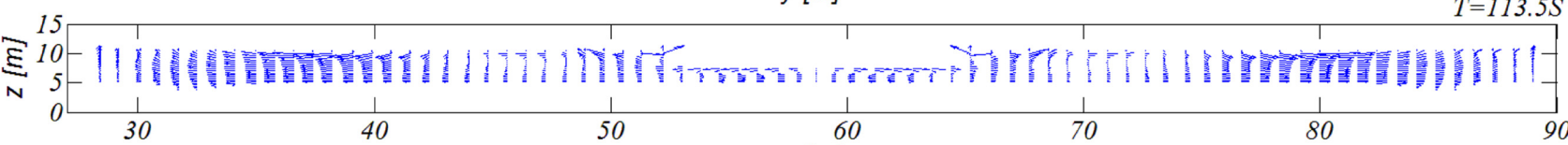

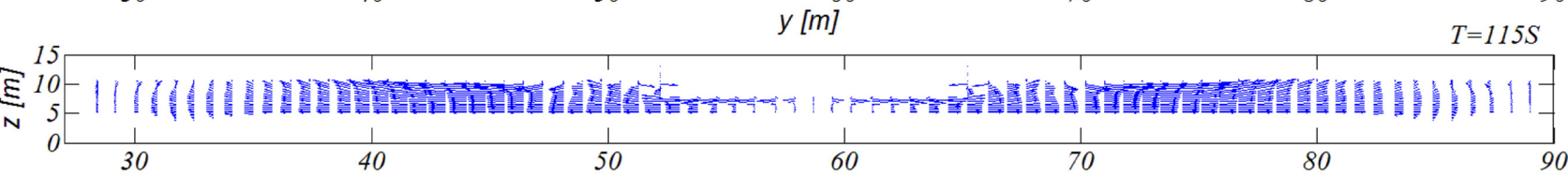

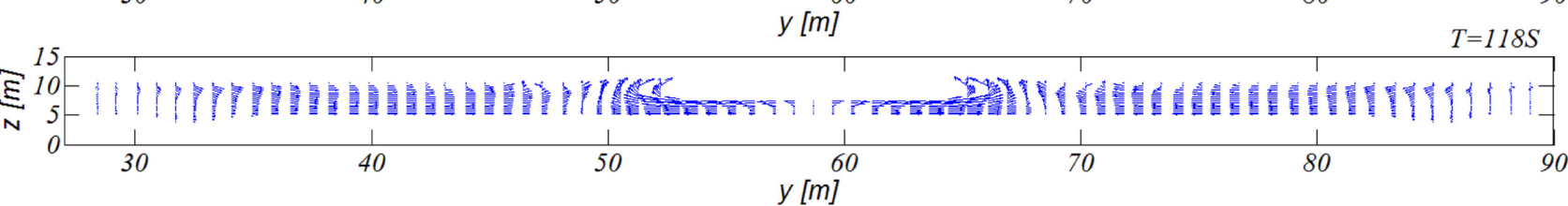

Fig. 24(d). Snapshots of water agitation in the channel as the ship are passing through the data acquisition point.

박의 적정 선속에 대한 기준조차 마련되어 있지 못한 실정으 로 이에 대한 연구가 시급해 보인다.

이러한 인식에 기초하여 본고에서는 먼저 Solitary wave 를 대상으로 한 Leading Depression N (LDN) Wave 조파 기법 (Zhao et al., 2012)을 수정하여, depth averaged 질량 보존식과 역적 운동량 식으로부터 항주파 해석모형이 제시 되었다. 이 해석모형에서 선수파 파고는 선속과 흘수로부터
비교적 용이하게 산출할 수 있다. 이어 현재 검토가 진행 중 인 송도 운하를 구성하는 다섯 개의 협수로를 대상으로 선 박 운행시 생성되는 고립파 특성과, 고립파 제어에 필요한 적정 선속을 결정하기 위한 수치모의가 삼차원 Navier Stokes 식과 VOF에 기초하여 수행되었다. 수치모형의 검증 은 현재 우리에게 가용한 운하 설계기준 중 가장 빈번히 언 급되는 PIANC (1987) 설계안과 본고에서 유도된 해석 모 


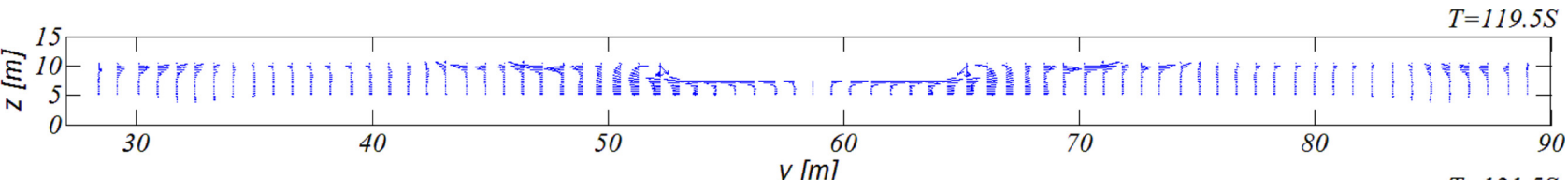

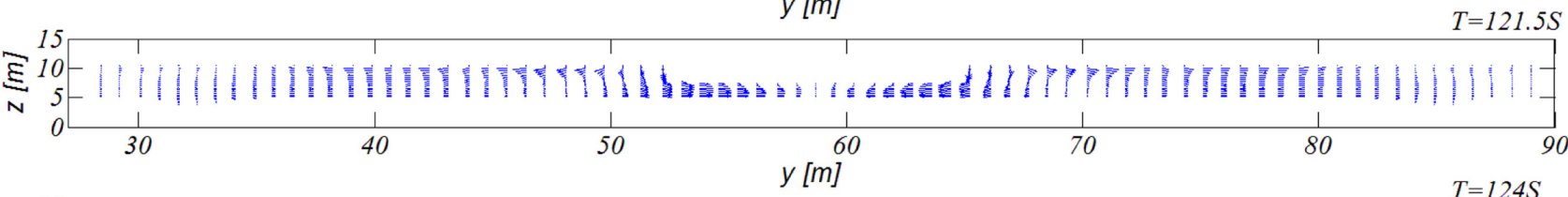

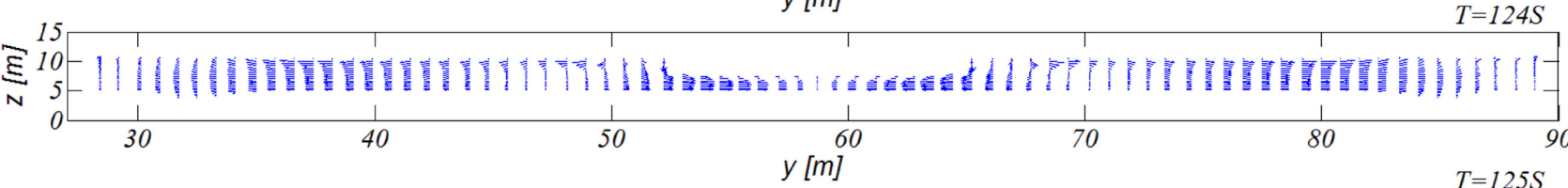

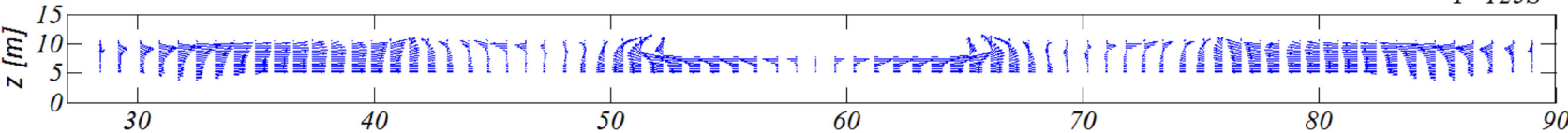

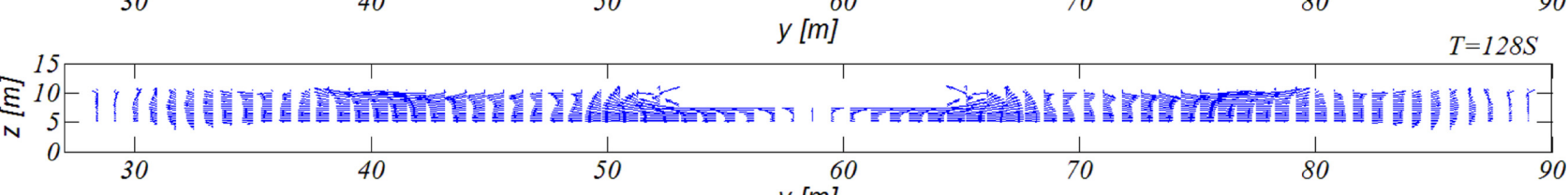

$y[m]$

Fig. 24(e). Snapshots of water agitation in the channel as the ship are passing through the data acquisition point.

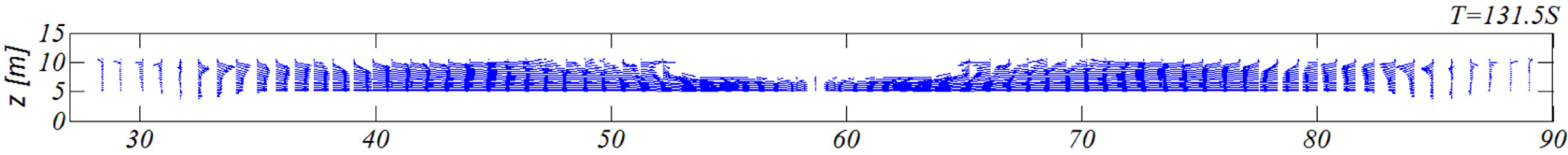

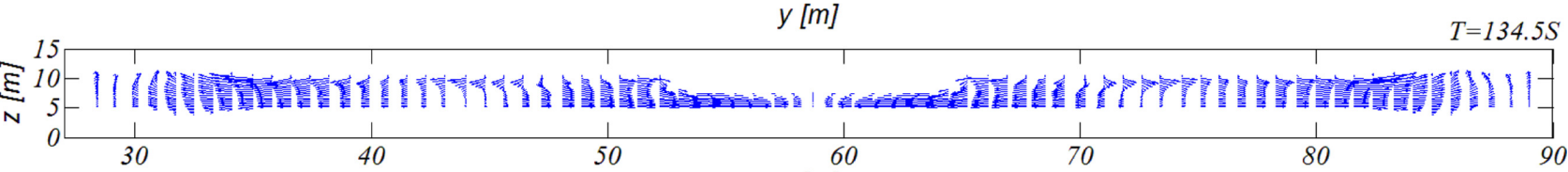

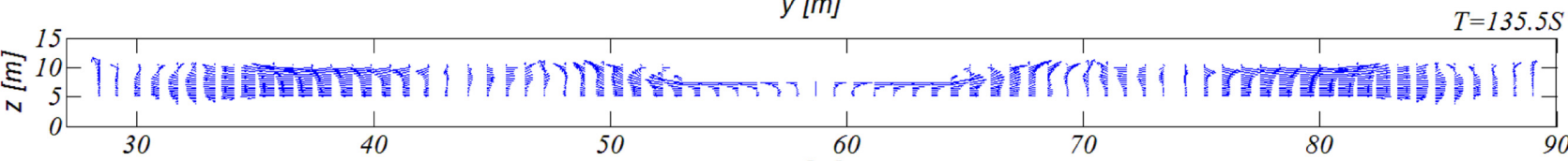

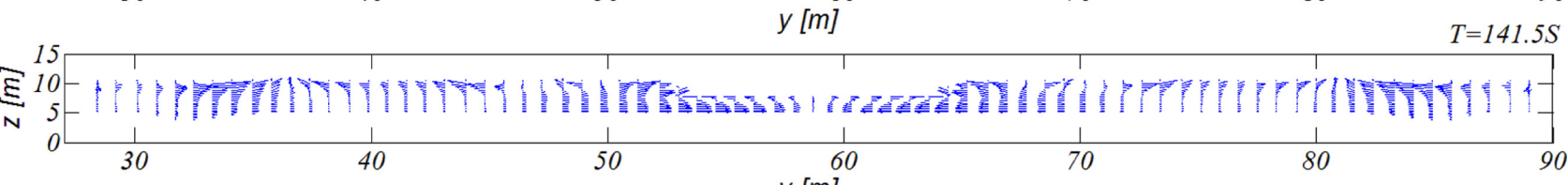

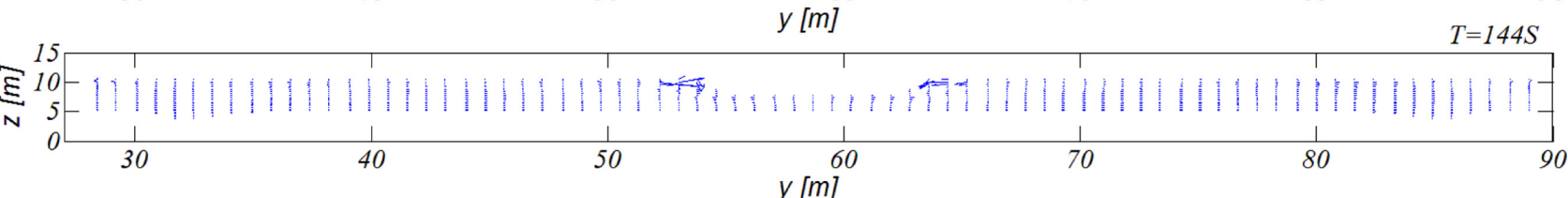

Fig. 24(f). Snapshots of water agitation in the channel as the stern of ship are passing through the data acquisition point.

형을 사용하여 수행되었다.

모의 결과 폭이 좁은 수로에서는 고립파 형태의 항주파가 생성된다는 본고의 가설과 일치하는 고립파 형태의 항주파가 생성되며, 선박 전면수역에 생성된 고립파는 고립파 파속으 로 알려진 $\sqrt{g(h+A)}$ 의 속도로 전파되는 것을 확인하였다. 또한 양안에서 진행되는 반사로 선박 전연수역에는 상당한 요 동이 오랜 기간 지속되는 것을 확인할 수 있다.
이와 더불어, 하안 인근에서 계측된 선수파 파고의 경우 수 치모의 결과는 PIANC (1987) 설계안을 상회하였으며 상당 히 오랜 기간 (이십초 내외) 지속되었다. 선미파의 경우는 하 회하였다. 이러한 결과는 광역수로에서 관측되는 항주파의 일 반적인 특성과는 상이한 것으로 좁은 수로폭이 항주파 특성 에 상당한 영향을 미치는 것으로 판단된다.

본고에서 제시된 해석모형의 경우 선속이 빠른 경우 

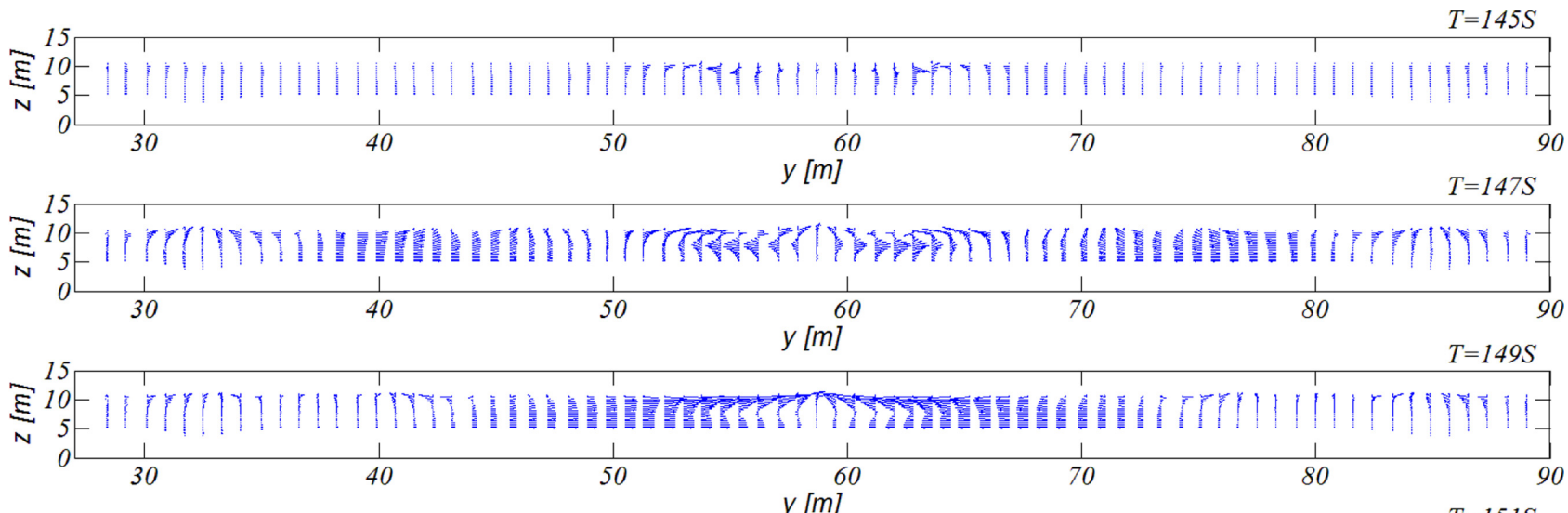

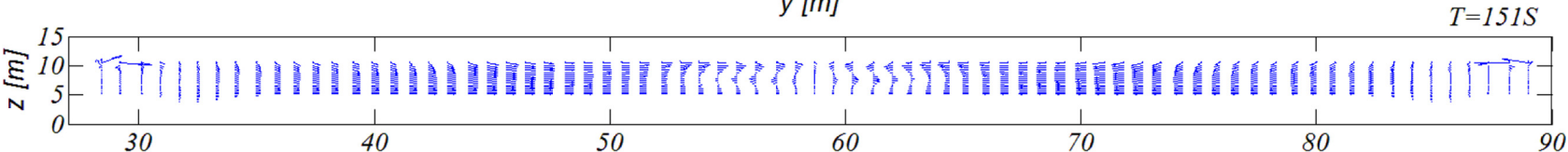

$y$ [m]

$T=153 S$

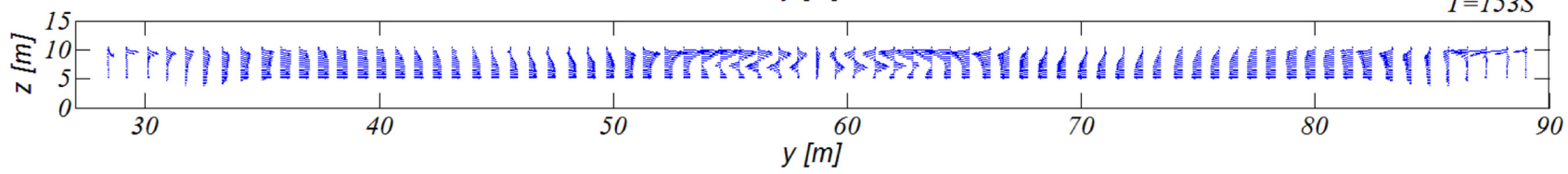

Fig. 24(g). Snapshots of water agitation in the channel due to stern waves after the ship leaves the data acquisition point.
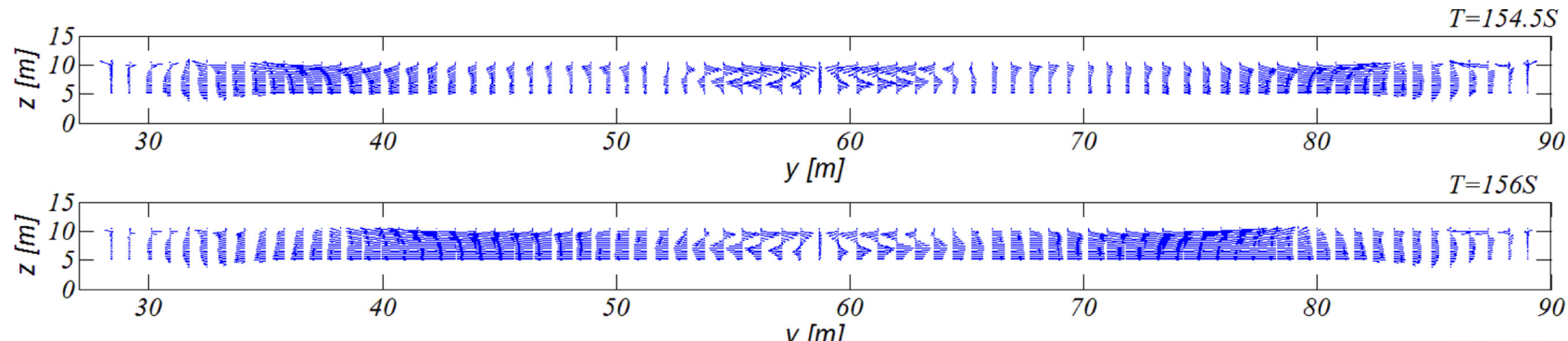

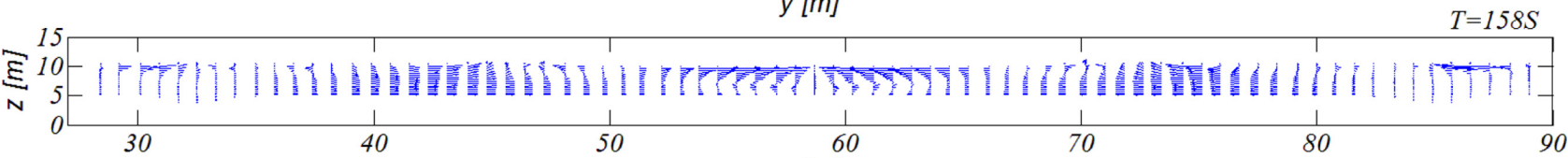
$y[\mathrm{~m}]$
$T=159 S$
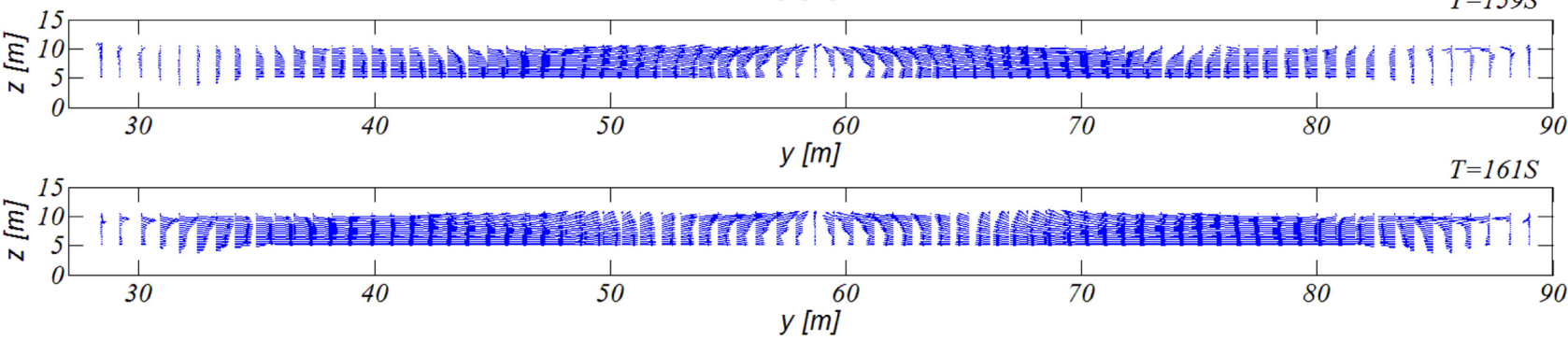

Fig. 24(h). Snapshots of water agitation in the channel due to stern waves after the ship leaves the data acquisition point.

$\left[V_{s}=10.69,8.74 \mathrm{knots}\right]$, 수치모의결과를 $10 \sim 15 \%$ 상회하는 수치를 제공하나, 선속이 감속할수록 전술한 오차는 급격하게 작아졌다. 이러한 차이는 해석모형의 유도과정에 수행된 이 상유체라는 가정과 선박 선수부의 곡면을 평면으로 가정한 점 을 상기하면 수용 가능한 수치로 보인다. 따라서 수치모의가 불가한 경우 보수적인 항주파 산출과정에 활용되면 유용한 정 보를 제공할 수 있다고 판단된다.
또한 선박의 협수로 통과시 선박을 중심으로 양안으로 진 행되는 흐름과, 반사로 인해 양안에서 선박으로 진행되는 흐 름이 교대로 출현하였으며 이 때 최대 $0.90 \mathrm{~m} / \mathrm{s}$ 의 유속이 전 수심대역에서 비교적 균일하게 유지되었다. 이러한 결과는 Confined 수로를 대상으로 한 Maynord (1996)와 Taylor et al.,2007의 연구결과와 일치하는 것으로, 상당한 쇄굴이 진행 될 수 있음을 의미한다. 


\section{References}

Japanese Ministry of Land, Infrastructure, Transport and Tourism, (1999). Guideline for the design of harbor.

HCCL (2005). "Burlington Channel Ship Movement and Channel Scour Investigation". HCCL, Kingston, Canada.

Herbich, J.B., and Schiller, R.E., (1984). "Surges and Waves Generated by Ships in a Constricted Channel", Coastal Engineering1984. New York, USA. ACSE, pp. 3213-3226.

Keulegan, G. H. (1948). "Gradual damping of solitary waves". J. Res. Natl. Bur. Stand. 40:487-498.

Maynord, S.T. (1996). "Return velocity and drawdown in navigation channels", US Army Engineer Waterways Experiment Station, Vicksburg, Mississippi, 1996, Technical Report HL-96-7.

Maynord, S.T. (2004). "Ship effects at the bank line of navigation channels". Maritime Engineering, 157(MA2), 93-100.

PIANC (1987). "Guidlines for the design and construction of flexible revetments incorporating geotextiles for inland waterways". Supplement to Bulletin no 57, report of InCom WG04, PIANC, Brussels.
Russel, J.S. (1983). "Report of the Committee on Waves". Rep. Meet. Br Assoc. Adv. Sci. 7th. Liverpool, 1987, John Murray, London 417-496.

Taylor, D.R., Hall, K. and Macdonald N. (2007). "Investigations into ship induced hydrodynamics and scour in confined shipping channels", Journal of Coastal Research, SI 50 (Proceedings of the $9^{\text {th }}$ International Coastal Symposium, 491-596. Gold Coast, Austrslia.

Zhao, X., Wang, B. and Liu, H. (2012). Characteristics of tsunami motion and energy budget during runup and rundown processes over a plane beach. Physics of fluids 24, 062107.

Received 14 May, 2015

Revised 31 July, 2015

Accepted 14 August, 2015 